Portland State University

PDXScholar

Dissertations and Theses

Dissertations and Theses

Summer 9-30-2013

\title{
"Game Over" for the Climate: The Keystone XL Pipeline on TV News
}

\author{
Elisabeth Wilder \\ Portland State University
}

Follow this and additional works at: https://pdxscholar.library.pdx.edu/open_access_etds

Part of the Mass Communication Commons, and the Social Influence and Political Communication Commons

Let us know how access to this document benefits you.

\section{Recommended Citation}

Wilder, Elisabeth, "'"Game Over" for the Climate: The Keystone XL Pipeline on TV News" (2013).

Dissertations and Theses. Paper 1438.

https://doi.org/10.15760/etd.1437

This Thesis is brought to you for free and open access. It has been accepted for inclusion in Dissertations and Theses by an authorized administrator of PDXScholar. Please contact us if we can make this document more accessible: pdxscholar@pdx.edu. 
"Game Over" for the Climate:

The Keystone XL Pipeline on TV News

by

Elisabeth Wilder

A thesis submitted in partial fulfillment of the requirements for the degree of

\section{Master of Arts \\ in \\ Sociology}

Thesis Committee:

Veronica Dujon, Chair

José Padín

Amy Lubitow

Portland State University

2013 
C2013 Elisabeth Wilder 


\begin{abstract}
The overwhelming consensus of the world's climate scientists is that we must rapidly reduce our greenhouse emissions if we are to avoid catastrophic and irreversible climate change. Yet the proposed Keystone XL pipeline, which would carry tar sands oil that emits three to four times the carbon emissions of conventional gasoline across the U.S., is supported by a solid majority of Americans. This level of support for a project that would dramatically increase greenhouse gas emissions, pollute sensitive lands and water sources, and threaten the health and safety of communities along the way begs the question: what kind of information have Americans received about the pipeline?

Relying on theoretical perspectives developed by scholars who examine power structures, ideology, and the political economy of the mass media, I analyze 177 national network and cable news broadcasts in order to determine what kind of information leading media sources provide to the public about the Keystone XL pipeline proposal and the context in which this information is presented. Content analysis of broadcast transcripts reveals that television news stations exhibit biased coverage that encourages viewers to support pipeline construction. Furthermore, television news stations marginalize environmental and social concerns and disproportionately rely on business and government sources for information. Finally, the dominant frame employed by the news media is informed by neoliberal ideology and offers no challenge to the preferences of corporate and government elites-including the continued dominance of the fossil fuel industry. This type of coverage affords viewers a very limited basis for understanding the environmental and ultimately social threats posed by Keystone XL.
\end{abstract}




\title{
DEDICATION
}

\author{
for \\ Charlotte Rose \\ and \\ Duke Snow \\ my first and greatest teachers
}




\section{ACKNOWLEDGEMENTS}

First and foremost, I would like to thank my committee—Veronica Dujon, José Padín, and Amy Lubitow—-for their expertise, insight and guidance throughout this entire process. I could not have done this without you, and I am sincerely grateful. I would also like to extend special thanks to Bob Liebman for his unwavering enthusiasm and support, and to the rest of the Sociology faculty and staff at Portland State. To my cohort, for the camaraderie and good company during these past two years-you are part of the "friends and family" section now. Special thanks to Patrick Smith, for his astute feedback and encouragement at each stage of this project.

I would also like to thank my undergraduate mentors: Errol Henderson, for advising me not only on how to write but also on what is worth writing about; Asma Abbas, for charting a first course through the wilderness of theory and "the political"; and Terri Anderson, for teaching the kind of social science that really matters.

Thanks to my friends and family, for the support and occasional reminders that there is a world beyond the pages of this thesis. Thanks especially to Sharon Deegan and Chloe, Walker, and Daphne Faison, who have been there during the best and worst of times and always managed to help me find the light. To my grandmother Phyllis for her steadfast love and devotion to her family, and my grandfather Duke, whose wisdom, songs, and knowledge of the natural world continue to inspire me. And to my mom, Charlotte: thank you doesn't begin to cover it. Anything that I have accomplished belongs in equal part to you. 
Finally, to Kyle Young: thank you for your thoughtfulness, patience and good humor during these past two years; for making our home cozy while I did far less than my fair share; for listening to and believing in me when I needed it most; and for walking with me to the cliff's edge and making sure that I jump. I am more grateful than I could possibly say, and I look forward to our next adventure together. 


\section{TABLE OF CONTENTS}

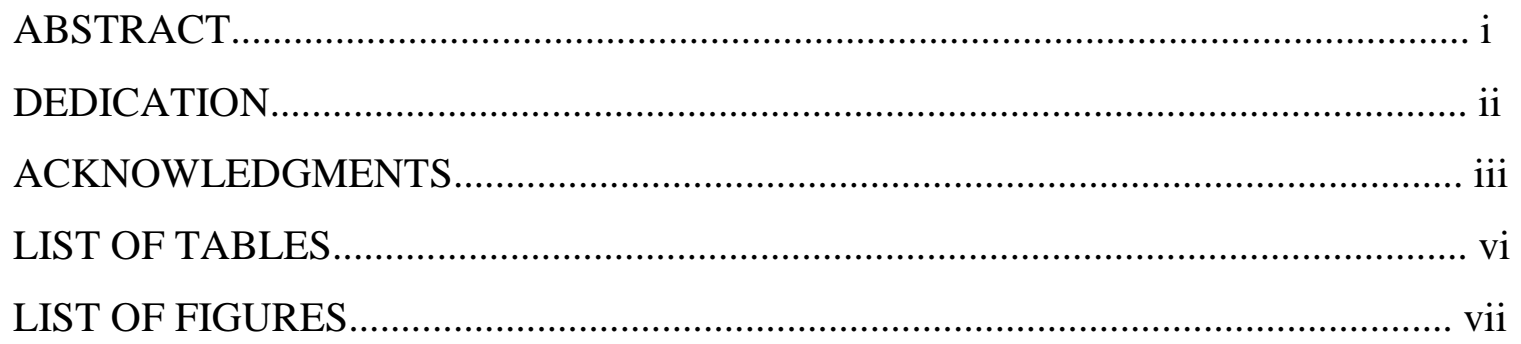

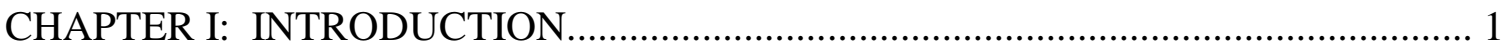

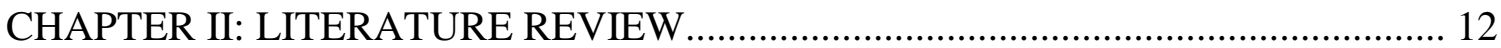

CHAPTER III: THEORETICAL FRAMEWORK....................................................... 20

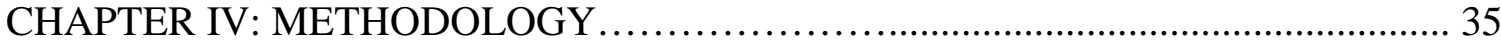

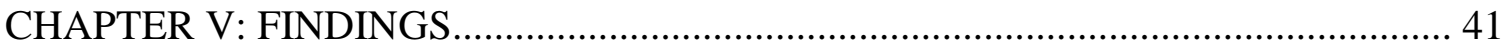

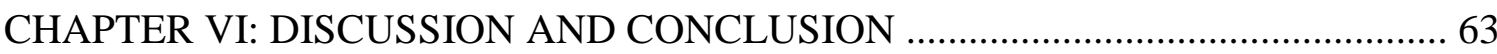

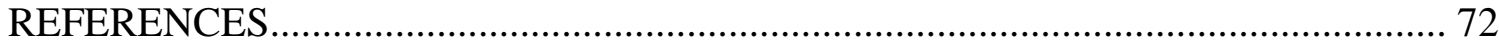

APPENDIX A: Frame Matrix ………………………............................................ 79

APPENDIX B: Code Sheet..................................................................................... 80 


\section{LIST OF TABLES}

Table 1: Broadcasts Mentioning Keystone XL............................................................ 44

Table 2: Issue Mentions ....................................................................................... 49

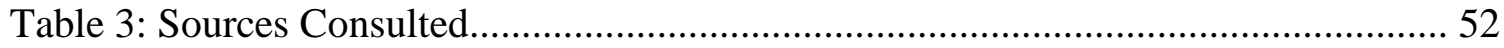

Table 4: Prominent Frames................................................................................... 57 


\section{LIST OF FIGURES}

Figure 1: Television News Stories, 2008-2012 _................................ 42

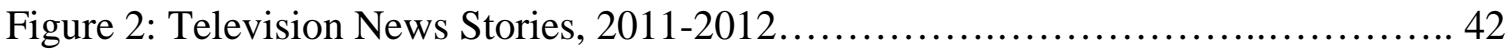

Figure 3: Favorable and Opposing Claims, by Station........................... 45

Figure 4: Prominent Ideas Featured in Keystone XL Segments...................... 50 


\section{CHAPTER I: INTRODUCTION}

The Keystone XL pipeline was proposed by the Canadian energy corporation TransCanada in 2008 to transport tar sands oil from Canada to refineries on the Gulf Coast. If built, the pipeline would traverse six U.S. states and cross several major rivers, federally protected wetlands, and key water sources—including the Ogallala Aquifer, which supplies approximately a third of all water used for drinking and irrigation in the United States (U.S. Department of State 2011). Extracting, transporting and refining tar sands oil is highly energy intensive, and results in three to four times more carbon emissions over its life cycle than most other petroleum products (Charpentier et al. 2009). James Hansen, NASA scientist and eminent climatologist, has publicly stated that if the Keystone pipeline is built, it will be "game over" for the climate (Hansen 2012). Removing and burning all that oil, Hansen argues, would result in catastrophic and irreversible climate damage. However, 57 percent of the American public currently believes that the pipeline should be approved (Gallup, Inc. 2012). This level of support for a project with the potential for such serious ecological and social disruption begs the question: what kind of information have Americans received about the pipeline, and in what context is this information presented? Moreover, what is the relationship between how the Keystone XL pipeline proposal is framed and the political economy of the mass media?

We know that media presentations of issues profoundly influence public opinion and eventual outcomes (Iyengar 1991). Studies show that the way that issues are covered play a major role in shaping public opinion as well as determining the boundaries of the 
debate. For instance, Page and Shapiro $(1987 ; 1992)$ found that when news broadcasts favor one side of an issue, popular support for that particular point of view increases, and Mazur (2006) empirically showed that public concern about an alleged hazard waxes with increasing news coverage and wanes with diminishing coverage. This thesis attempts to understand how the content and presentation of information in leading media sources shapes U.S. public opinion about the Keystone XL pipeline proposal, and what motivates the media's framing choices. Relying on theoretical perspectives developed by scholars who examine power structures, ideology, and the political economy of the mass media, this study employs content analysis of national network and cable news broadcasts in order to determine what kind of information leading media sources provide about the Keystone $\mathrm{XL}$ pipeline, the context within which it is presented, and how the pipeline proposal is framed. As the majority of Americans get most of their information from television news broadcasts (Morris 2005; National Science Foundation 2010; The Pew Research Center 2010), this research examines news segments on leading national network ( $\mathrm{ABC}, \mathrm{CBS}$, and $\mathrm{NBC})$ and cable (CNN, MSNBC, and $\mathrm{FOX})$ television stations. In order to situate this research within a thematic context, this chapter presents a brief background on relevant topics including climate change, the history and implications of the Keystone XL pipeline proposal, environmental justice and fossil fuel consumption, and the role of the news media in shaping the public's perception of climate change. 


\section{Background on Climate Change}

In 1992, more than 1,500 of the world's most distinguished scientists (including half of all living Nobel Laureates) signed the "World Scientists Warning to Humanity." The scientists stated that:

"Human beings and the natural world are on a collision course. Human activities inflict harsh and often irreversible damage on the environment and on critical resources. If not checked, many of our current practices put at risk the future we wish for human society and the plant and animal kingdom, and may so alter the living world that it will be unable to sustain life in the manner that we know. Fundamental changes are urgent if we are to avoid the collision our present course will bring." 1

Their statement warns us that human beings are transforming the earth on a scale that rivals geologic and evolutionary processes. Rees and Westra (2003) point out the fact that half of the world's forests and wetlands are gone; seventy percent of the planet's fish stocks are being fished at or beyond their sustainable limits; biodiversity loss is occurring at between 100 and 1000 times its natural rate; and one quarter of the earth's bird species have been driven into extinction as a result of human activities. Humanity now fixes more nitrogen in the atmosphere than all natural terrestrial processes combined. Atmospheric carbon has increased by $30 \%$ since the Industrial Revolution and is now higher than at any point in the last 160,000 years. Mean global temperature has reached a record high, and the world is experiencing more frequent extreme climate-related events than ever before (Rees and Westra 2003). Many scientists, including top climate scientists and members of the U.N. Intergovernmental Panel on Climate Change, believe

\footnotetext{
${ }^{1}$ Foster $(2002: 73)$
} 
that global warming poses the gravest threat to the future of our planet and humankind (Foster 2002).

Climate change is caused by the accumulation of nitrogen, carbon, and other greenhouse gases in the atmosphere. Since the Industrial Revolution, the gases released as a result of human activity (e.g. the production and use of fossil fuels, livestock rearing, and deforestation) have increased exponentially. There is widespread consensus in the scientific community that these activities are responsible for increases in the earth's average temperature; in fact, fully three quarters of atmospheric warming since 1850 has been attributed to anthropogenic sources (Boykoff 2007). Climate scientists also agree that warming trends will continue and increase in the coming years, and that unless we are able to rapidly reduce our greenhouse emissions in this century, we risk reaching tipping points and causing irreversible ecological damage-such as a sea-level rise that

will gradually inundate coastal areas, beach erosion and flooding from coastal storms, dramatic shifts in precipitation patterns, increased risk of serious droughts and floods, threats to biodiversity, and a number of potential challenges for public health (Pew Center on Global Climate Change 2011).

\section{Keystone XL: “Game Over” for the Climate}

The overwhelming consensus of the world's most renowned scientists is that we must move away from fossil fuels and find clean, sustainable sources of energy before it is too late. This is particularly urgent in the United States, where a fourth of the world's greenhouse emissions are produced. Extracting, transporting and refining tar sands oil 
results in three to four times more carbon emissions over its life cycle than most other petroleum products (Charpentier et al. 2009).

Supporters of the Keystone XL pipeline proposal argue that investing in tar sands oil production would lower gas prices, create thousands of jobs, and increase national security and energy independence. During an era of instability marked by economic recession and high levels of unemployment, these arguments speak to the concerns of many Americans. However, the only independent study of the pipeline to date concludes that oil from the pipeline would not reach markets anytime soon, that the pipeline would create only about 2,000 temporary jobs, and that the refined oil will be exported to Asia and will therefore not contribute to American energy independence or national security (Cornell University Global Labor Institute 2011). Furthermore, opponents of the pipeline argue that continued dependence on fossil fuels is unsustainable, that the pipeline would encourage production of a particularly dirty form of crude oil, and that the project would seriously threaten sensitive lands and water sources along its route. Other criticisms of the project include water waste and pollution during the extraction process, strip mining of pristine forest and indigenous lands, toxic oil spills, and adverse health impacts on people living downstream (Friends of the Earth 2012). The State Department's own environmental impact assessment of the pipeline found that even if environmental protection measures are followed, oil spills are likely and could result from corrosion, defects in materials or construction, pressure, ground movements, and flooding (U.S. Department of State 2011). In addition to creating serious ecological hazards, these oil spills also impact human communities-especially low income and minority 
communities, who are more likely to live near environmental hazards (Faber 2008). These communities are also more vulnerable to adverse health impacts because health care is usually less available to them (U.S Department of State 2011). The existing section of the Keystone pipeline experienced a dozen oil spills in its first year of operation, including a spill that discharged 21,000 gallons of crude oil onto lands adjacent to the pipeline (U.S Department of State 2011). Other pipelines have also experienced major spills in recent years: an Enbridge Energy pipeline leaked more than 840,000 gallons in 2010, polluting the Kalamazoo River in Michigan; a Chevron pipeline spilled 33,000 gallons into Red Butte Creek in Utah (followed by a second spill in the same area seven months later); an Exxon Mobil pipeline dumped 63,000 gallons of oil in 2011 into the Yellowstone River in Montana; another Chevron pipeline broke in March of 2013, spoiling sensitive wetlands in Utah; and another Exxon Mobil pipeline discharged nearly 500,000 gallons into a community in Arkansas in April of 2013, necessitating the evacuation of 22 homes (The New York Times 2013). Despite these hazards, the State Department's environmental review concluded that the pipeline would have "limited adverse environmental impacts" (U.S Department of State 2011).

Serious questions about conflict of interest and improper political influence on the State Department's review process have also been raised by independent observers. In 2011 it was revealed that Cardno Entrix, the firm hired to conduct the environmental impact study, had been hired at TransCanada's recommendation (The New York Times 2012). Cardno Entrix had previously worked on projects with TransCanada and had described TransCanada as one of its major clients. Furthermore, TransCanada's chief 
lobbyist, Paul Elliott, was a top aide in Hillary Rodham Clinton's 2008 presidential campaign (The New York Times 2012). Furthermore, emails between lobbyists for TransCanada and State Department officials revealed a warm and collaborative relationship between TransCanada and the State Department officials (The New York Times 2012).

Substantial public opposition to the pipeline arose during the summer of 2011, when 1,252 people were arrested in front of the White House as they demonstrated against the pipeline. In November 2011, 12,000 people encircled the building in symbolic protest of Keystone XL. House Republicans tried to force a quick decision on the pipeline by attaching it to the end-of-year payroll tax cut extension bill, but President Obama delayed the pipeline decision, citing the need for more time to conduct a comprehensive environmental review (The New York Times 2012). TransCanada subsequently announced plans to reroute the pipeline so that it would avoid the sensitive Sand Hills region of Nebraska and the Ogallala Aquifer and reapply for a permit. Meanwhile, it began construction on the southernmost portion of the pipeline from Cushing, Oklahoma to the Gulf Coast which, due to the fact that it would not cross any international borders, did not need presidential approval. In the spring of 2012, President Obama stood in front of a pipeline construction site in Oklahoma and declared that the Gulf Coast portion of the pipeline was a priority for his administration, and TransCanada re-submitted its proposal to the agency to build the northern, trans-border segment of Keystone XL. Immediately, protesters descended on construction sites in Texas and Oklahoma, staging sit-ins, blockades, and other acts of civil disobedience. Protesters 
spoke out against the environmental degradation associated with the pipeline as well as the United States government's refusal to recognize the threat posed by climate change.

\section{Environmental Justice and Fossil Fuel Consumption}

The wealthiest fifth of the world consumes more than $80 \%$ of the planet's resources (including fossil fuels) and produce more than $90 \%$ of its hazardous waste (Rees and Westra 2003). Fewer than 10\% of the world's inhabitants own cars, yet CO2 emissions (largely from automobiles) now threaten the stability of the planet (Foster 2002). And it is the poorest, most vulnerable members of the world community who suffer most when ecosystems are degraded or collapse, as they are most dependent on local ecosystems for their livelihoods (Rees and Westra 2003). At the dawn of the twentieth century, 25 million environmental refugees (i.e. those seeking shelter from violent weather events and ecological degradation) in the developing world fled from the countryside to overcrowded, underserved cities and outnumbered political refugees for the first time in history (International Red Cross 1999 in Rees and Westra 2003). Rees and Westra (2003) argue that the non-essential consumption patterns of the most privileged inhabitants of the earth translate into acts of violent harm against the vast majority of the world's population.

Fossil fuel consumption is a particular problem in the United States, where Americans (who represent only 4 percent of the world's population), produce a quarter of all greenhouse gas emissions (Boykoff 2007). The United States was the only industrialized nation to not sign and ratify the Kyoto Protocol in 1997, which was a 
roadmap for industrialized countries to stabilize and reduce their carbon dioxide emissions to 5\% below 1990 levels (Foster 2002). While The United Kingdom, Sweden, Germany, France, Belgium, and the Netherlands have since followed through on commitments to reduce greenhouse gas emissions, in the United States, emissions have actually increased to $20 \%$ above 1990 levels (United Nations Framework Convention on Climate Change 2012). Today, when asked to rank the importance of twenty-one policy issues, Americans list climate change last (The Pew Research Center 2010). The way that climate change is covered in the news media has a substantial impact on the public's perception of the issue.

\section{Climate Change and the Role of the News Media}

News is jointly created by stakeholders who promote their agendas to media representatives and by media representatives and owners who decide which stories will be covered and in what manner (Gamson and Modigliani 1989). The outcome of this process determines what type of information the public receives about important issues. As McCright and Dunlap note, the possibility of large-scale efforts to address climate change are "far more threatening to American industry, prosperity, lifestyles, and the entire 'American way of life' than are traditional pollution control measures" (2003: 353). They find that, beginning in the early 1990s, corporate funded think-tanks were able to take advantage of the media's "balancing norm" (i.e. the equation of "objectivity" with presenting "both sides of the story") to challenge climate science in the news and thereby protect corporations with primary investments in the fossil fuel industry. Claims 
about the existence of climate change became more contested in the U.S. policy arena, despite clear consensus in the scientific community—and public opinion has followed the same trajectory. In 1997, an overwhelming majority of the U.S. public believed that climate change is a real problem that required action (Program on International Policy Attitudes 1998:1 in McCright and Dunlap 2003); ten years later, only 57 percent of Americans believed that there is solid evidence for climate change and humanity's role in it (The Pew Research Center 2009). This is in contrast to a worldwide average of 79 percent (BBC World Service 2007).

\section{Research Questions}

As the seriousness of the threat of climate change becomes ever more apparent, the Keystone XL pipeline decision has emerged as the unequivocal litmus test of the United States' political will to address climate change. Given the extraordinary influence of the mass media on public opinion, this research employs content analysis of national network and cable news broadcasts in order to determine how the Keystone XL pipeline is presented to the American public. The following research questions are explored:

1. What kind of information is being provided about the Keystone XL pipeline proposal?

2. What is the context in which the pipeline proposal is presented?

3. Who shapes the discourse about the pipeline proposal? What political and economic interests do they represent?

4. What are the frames employed to discuss the pipeline proposal? What is the relationship between these frames and the political economy of the mass media? 
Although there is ample research on the media's coverage of environmental issues in general, I was unable to find any studies that specifically addressed the Keystone XL pipeline proposal. This research serves to fill that gap. Furthermore, analysis of media coverage of the Keystone XL pipeline debate provides a unique opportunity to observe whether, given what we know about global climate change in the $21^{\text {st }}$ century, the discourse surrounding fossil fuel use in the media has shifted.This study will evaluate the information, context and framing provided by leading media sources about the Keystone XL pipeline in order to help explain U.S. public opinion about the project. It will also address broader theoretical concerns about inequalities in power and access to resources as well as the role of ideology in news discourse.

Iyengar (1991) argues that the television news media effectively set the political agenda, as the themes and issues repeated on television news are the ones that become viewers' priorities. With this research in mind, the next chapter of this thesis presents a review of the literature on framing and representations of fossil fuel-related environmental issues in the mass media. Chapter 3 outlines the theoretical framework which informs this study. Chapter 4 details the methodology of this project and outlines the coding scheme and coding protocol. Chapter 5 presents the findings of this thesis: the type of information provided by the mass media is discussed; the context and sources consulted are analyzed; and the frames employed to discuss the pipeline are described. Chapter 6 revisits the research questions guiding the thesis, and the findings are interpreted in light of the initial aims of the study. The chapter concludes with a brief summary of the findings and a discussion of the research implications. 


\section{CHAPTER II: LITERATURE REVIEW}

While there are no empirical analyses of media representations of the Keystone XL pipeline, there is ample research on the media's coverage of other fossil-fuel related environmental issues. This chapter presents a brief review of the literature on framing, then turns to media representations of climate change and oil spills.

\section{Media Frames}

The media plays a central role in facilitating people's interpretations of important issues through the process of framing (Goffman 1974). Media frames can be understood as interpretive storylines that set a specific train of thought in motion, communicate why an issue might be a problem, who or what might be responsible for it, and what should be done about it (Nisbet and Myers 2007). They provide central organizing principles that hold ideas together and give them coherence and meaning (Gamson et al. 1992). Frames by definition "select some aspects of a perceived reality and make them more salient" as they "promote a particular problem definition, causal interpretation, moral evaluation, and/or treatment recommendation" (Entman 1993:52). In other words, they draw the audience's attention to a specific part of some larger picture in order to tell a particular story. The media usually supplies a central frame for interpreting a particular event, and present dissenting views in order to appear balanced (Widener and Gunter 2007). Presenting multiple sides of a controversial issue, Widener and Gunter suggest, "allows the media to project an image of objectivity, even though all views are not rewarded equal coverage" (2007: 769). 
Episodic frames, as identified by Iyengar (1991) are focused on particular cases, while thematic frames place issues in a wider socio-political context. The essential difference is that episodic frames present concrete events while thematic frames present collective or general evidence about a larger theme. On television, political news is distinctly episodic — and issues that cannot be reduced to specific events are seldom covered at all (Iyengar 1991). This is at least partly because, given the structure of television news, there simply is not enough airtime available to provide a thematic background on each issue that is deemed newsworthy (Iyengar 1991). However, this means that viewers who rely on television news are expected to make decisions about important issues for which they have been provided virtually no context. Exposure to episodic news also makes viewers less likely to hold public officials responsible for social problems, decreasing the public's control over their elected representatives and the policies they pursue (Iyengar 1991: 3). Episodic frames also imply that endemic social problems are mere disputes that will soon be resolved rather than permanent conflicts of interest (Gans 1979). In addition, because they "lack systematic political and social analysis that indicates the sources of, relationships between, and consequences of individual events" (Bagdikian 1997:71), episodic news frames offer no challenge to the existing power structure or the preferences of corporate and government elitesincluding the continued dominance of the fossil fuel industry.

The way an issue is covered the news can profoundly influence public opinion and eventual outcomes (Iyengar 1991). Page and Shapiro (1987; 1992) found that when news broadcasts favor one side of an issue, popular support for that particular point of 
view increases, and Mazur (2006) showed that the nations in which environmental risks were most often covered in the news had the highest perceptions of environmental dangers, while nations with the least amount of news coverage had the lowest perceptions of environmental dangers. Finally, individuals who were exposed to a thematic frame had more support for policies that address climate change than those exposed to an episodic frame (Hart 2011).

These studies illustrate the way in which the television news media effectively set the political agenda, as the themes and issues repeated on television news are the ones that become viewers' priorities (Iyengar 1991). The media therefore provide more than information: they also provide cues as to what topics are important and which are not, as well as how the issues that are discussed should be understood. The issues emphasized by the media are the ones the public comes to regard as significant (Iyengar 1991). This process is illustrated by the mainstream media's coverage of climate change and changes in public opinion over time.

\section{Climate Change in the Media}

As the international consensus on climate change began to take shape in the mid1980s, media coverage of climate science and policy increased dramatically (Boykoff 2009). By the mid-1990s, an overwhelming majority of the U.S. public believed that climate change was a real problem that required action (Program on International Policy Attitudes 1998:1 in McCright and Dunlap 2003). However, by the 1990s and 2000s, media coverage of climate change in general had tapered off, and tended to rise only in 
conjunction with high-profile climate-related events (e.g. publication of IPCC and Stern reports, the release of Al Gore's film An Inconvenient Truth) and fall during periods of economic crisis or war (Boykoff and Boykoff 2007; Boykoff 2009). In 2009, only 57 percent of Americans believed that there is solid evidence for climate change and humanity's role in it (The Pew Research Center 2009).

Furthermore, despite the clear consensus in the scientific community, claims about the existence of climate change were regularly contested in the media during the 1990s and 2000s. McCright and Dunlap (2003) argue that the conservative counterenvironmental movement, sensing a threat to its interests, began to mobilize conservative think tanks to challenge the claims of mainstream climate science. These think tanks published policy documents that cited fringe climate change skeptics as "experts," thereby circumventing traditional scientific channels (e.g., peer-reviewed articles and conference papers). McCright and Dunlap (2003) find that conservative think tanks were able to significantly shape the debate over climate change by sponsoring policy forums, lectures, and press conferences critical of mainstream climate science. Elected officials and media representatives were invited to these events, and transcripts were regularly disseminated to a wide range of policy-makers and media outlets. By the end of the decade, climate change skeptics had achieved relative parity with conventional (i.e. peerreviewed) climate scientists in the national print media (McCright and Dunlap 2003). By 2003, opponents of climate change legislation had surpassed environmental advocates in terms of the number of times each were mentioned (ibid) as they sought to undermine the 
scientific consensus on climate change and establish its "non-problematicity" (McCright and Dunlap 2000).

When climate change is covered in the media, it is often discussed in a way that diverges significantly from the scientific consensus on its causes. Boykoff (2007) finds that $70 \%$ of U.S. television news segments provided "balanced" coverage regarding anthropogenic contributions to climate change, demonstrating an informational bias by significantly diverging from the consensus view that humans contribute to climate change. Among cable television outlets, FOX was found to be more likely to take a dismissive tone toward and emphasize the uncertainty of climate science than $\mathrm{CNN}$ or MSNBC (Feldman et. al 2011). This is significant because an analysis of 2008 data from a nationally representative survey shows a negative association between Fox News viewership and acceptance of global warming, even after controlling for numerous potential confounding factors, while viewing CNN and MSNBC was associated with greater acceptance of global warming (Feldman et. al 2011).

Boykoff and Bokyoff (2004) argue that journalistic norms (e.g. personalization, dramatization, novelty, balance, reliance on authoritative sources) lead to "informationally deficient" coverage of climate change. The U.S. prestige press also tends to distort climate science by emphasizing uncertainty about the causes of climate change to a greater degree than their equivalents in New Zealand, Finland and the United Kingdom (Dispensa and Brulle 2003). While accounts of climate change in the U.S. press showed significant divergence from the scientific consensus, accounts in the U.K. press showed no major divergence (Boykoff 2007). However, Carvalho (2005) found that the 
British quality press's analysis of the governance of climate change still "remained within the broad ideological parameters of free-market capitalism and neoliberalism, avoiding a sustained critique of the possibility of constant economic growth and increasing consumption, and of the profound international injustices associated with the greenhouse effect" (Carvalho 2005: 21).

These findings echo Herman \& Chomsky's (1988) suggestion that the news media present the world in such a way that the status quo will be maintained for those with the greatest stakes in it. By emphasizing uncertainty about human causes, providing "both sides" of the story, and minimizing the threat of climate change, the media uphold current political and economic arrangements (which include continued dependence on fossil fuels) and the interests of elites with primary economic interests in maintaining them.

\section{Oil Spills in the Media}

Past research has established the domination of news coverage by business and government elites in the aftermath of fossil fuel-related disasters such as the Santa Barbara oil spill (Molotch and Lester 1975) and the Exxon Valdez oil spill (Daley and O’Neill 1991; Smith 1993). These events, much like the Keystone XL pipeline debate, raised politically sensitive questions about the environment and the economy, national energy policies, and the roles and responsibilities of multinational corporations.

Molotch and Lester (1975) find that in mainstream press accounts of the Santa Barbara oil spill, access to newspapers was greatest within the federal executive branch, 
followed by Congress, the oil companies, and state politicians. The views of federal officials and oil company representatives were featured in $91 \%$ of the stories in the national mainstream press, as compared to conservationists and local officials, who were featured only $9 \%$ of the time. Molotch and Lester also found that stories fitting the event needs of oil companies and the federal executive branch (e.g. oil companies' beach cleanup efforts, claims about technical advances that would prevent future spills, "tough" new regulations) are more likely to be featured in news stories than those fitting the needs of conservationist and local interests (e.g. the extensive ecological damage caused by the spill and harm to nearby communities) and that nationwide coverage of activities favorable to oil companies was far more extensive than favorable coverage of conservationists (93.2 vs. 6.8 percent).

In his analysis of mainstream press coverage of the Exxon Valdez oil spill, Smith (1993) finds a similar pattern: a majority (61 percent) of the sources consulted were corporate or government elites-i.e. representatives of the Alaskan and federal governments and/or the oil industry. Daley and O'Neill (1991) also find that mainstream coverage naturalized and individualized the spill by comparing it to a natural disaster (e.g. an earthquake) and focusing blame on a single person (e.g. the captain of the oil tanker)—both of which deflect attention from corporate responsibility and culpability. Although town residents were interviewed (seeming to lend diversity to the narrative), they were usually portrayed as "victims" expressing disbelief, disappointment, and powerlessness at forces beyond their control. A preponderance of the coverage clearly favored government and industry officials. Daley and O'Neill (1991) argue that this type 
of "disaster narrative" coverage can be interpreted according to Gramsci's definition of hegemony, in which the ruling coalition advances values and interest that are in line with the nucleus of the nation's economic activity (i.e. fossil fuel production). On the other hand, Widener and Gunter (2007) find that that the native Alaskan press provided competing frames that included assessing social and cultural injuries as part of the public discourse around the oil spill alongside economic and ecosystemic ones. They conclude that while the mainstream media commit fundamental errors of attribution by treating environmental disasters as novelties and failing to analyze the political and economic systems that made them possible, the Alaskan native press contextualized the spill and offered an alternative narrative and conceptualization of nature.

Widener and Gunter (2007) argue that alternative media help to empower marginalized groups by providing a venue for them to tell their own stories. As demonstrated by previous research, this opportunity is conspicuously absent in the mainstream media, which disproportionately favors the perspectives and interests of the powerful. From the perspective of democratic theory as well as that of social and environmental justice, this is significant: in the mainstream press, the public is not being provided with the whole story about issues of social and environmental import. In order to understand the reasons that this may be the case, I now turn to a discussion of the theoretical framework that guides this study. 


\section{CHAPTER III: THEORETICAL FRAMEWORK}

This research relies on the theoretical perspectives developed by scholars who examine power structures, ideology, and the political economy of the mass media. These conceptualizations are most relevant to understanding what motivates media framing choices. This chapter begins with theories of power in U.S. society and their implications for the health of the planet and its inhabitants. It then turns to a discussion of ideology and the role of the mass media in transmitting it, followed by theories on the political economy of the mass media. The chapter concludes with the research questions that guide this thesis and the significance of the study.

\section{Power Structures}

A key assumption of American democracy is that citizens have power through their elected representatives. However, Mills (1956) contends that power in U.S. society is actually concentrated among a small group of high-level corporate, government, and military leaders that he refers to as the power elite. The power elite effectively dominate the state, making state policy nothing more than a reflection of these elite interests (Mills 1956). Yet Block (1987) argues that even if the state is an instrument of elite interests, the fact that it "must appear otherwise indicates the need for a more complex framework" for analyzing it (Block 1987: 53). In Block’s analysis, instrumental elite domination of the state is unnecessary. As current political and economic arrangements are the basis of their power, structural mechanisms ensure that state managers will act in the long-term interests of capitalism. Since capitalist economies are based on the private investment 
decisions of capitalists, state managers tend to enact policies that facilitate and encourage private investment (e.g. minimal regulation of industry, low taxes, low wages) even if capitalists make no overt demands that they do so.

Although these structural mechanisms are powerful, they are not powerful enough in and of themselves to ensure corporate domination of government, especially in times of crisis (Domhoff 2005). This is because capitalists' structural power does not preclude the possibility that the state will pursue new economic arrangements during a crisis. As there is no necessary link between private ownership and the markets, government could create firms to compete in the market system, hire unemployed workers, and revive a depressed economy. Furthermore, structural power focuses on the relationship between corporations and the state; it says nothing about the relationship between corporations and society. It cannot guarantee that workers will docilely accept an ongoing economic depression, and corporate leaders need to make sure the government will protect their private property (e.g. warehouses, factories) in the case of violent conflict.

Capitalists therefore $d o$ engage in instrumental activities to promote their classbased interests (Domhoff 2005). Studies of corporate elite responses to the growing scientific consensus on climate change indeed show that they engaged in instrumental actions ranging from blatant manipulation of information (Crenson 1971; Molotch 1970) to more subtle "diversionary reframing" and consciousness lowering activities (Schnaiberg 1994) and manufacturing doubt on climate science (McCright and Dunlap 2003) that fundamentally changed the terms of the conversation in the news media as it reached the public. 
Domhoff (2005) argues that policy consensus does not arise naturally within the capitalist class. Instead, class consciousness arises through a series coordinating mechanisms that facilitate unity and a sense of common interest within the capitalist elite. These mechanisms include strategic alliances (e.g. joint ventures), shared social experiences (e.g. private schools, social clubs), participation in the policy-planning network (e.g. foundations, think tanks) and interlocking directorates. These coordinating mechanisms tie apparently independent institutions into a coordinative apparatus that allows the business elite to coordinate a broad range of societal sectors and implement society-wide social policy (Schwartz et al 1987). Schwartz et al. (1987) point out that these instrumental strategies help increase corporate assurance that when business needs (i.e., for maximum profit) conflict with the needs of the public (for a clean environment, well-made, affordable products and public transit), corporate interests will prevail.

State managers, with their focus on economic growth and job creation, tend to support a model of production that focuses on productivity and profit for capitalists at the expense of concerns such as workers' rights and environmental protection (Rudel, Roberts and Carmin 2011). This can be observed in elites' response to policy proposals that attempt to address the threat of global climate change. In 1997, although a large majority of American citizens favored ratification of the Kyoto Treaty (Program on International Policy Attitudes 1998:1 in McCright and Dunlap 2003), the United States Senate unanimously (95-0) passed Senate Resolution 98, which notified the Clinton Administration that the Senate would not ratify any treaty that would: (a) impose mandatory greenhouse gas emissions reductions for the United States without also 
imposing such reductions for developing nations, or (b) result in serious harm to the U.S. economy.

Foster (2002) argues that the Kyoto Protocol represented a very modest, mostly symbolic first step in addressing the trend of climate change. The treaty's emission reduction guidelines fell far short of the massive cuts most climate scientists said would be necessary to halt the trend of global warming — and the inability of advanced capitalist states to make these initial reductions, Foster argues, suggests that (1) carbon-based economies are endemic to capitalism and that (2) capitalist economies are unable to reverse their course. When weighted against the imperatives of capital accumulation the short-term profits to be made override the long-term risks, even if the health of the biosphere and the planet itself are threatened (Foster 2002).

\section{Hegemonic Ideology}

The rights of citizens to clean air and water often stand in the way of corporations making the greatest possible profit (Faber 2008). Gaining buy-in from the public for environmentally destructive policies therefore requires the transmission of an ideology that equates the interests of wealthy individuals and corporations with the needs of every day Americans (Hall 1995).

In the broadest sense, for Marx, ideology is a theory about the nature of consciousness (Parekh 1982). An ideology ascribes to thoughts, ideas and concepts an existence independent of human consciousness of which they are a product and abstracts ideas from their broader socio-historical realities (Parekh 1982). Moreover, according to 
Engels, the ideological process obscures the "real motive forces" impelling the thinker; the ideology is subsequently accepted "without examination as something produced by reason" (Parekh 1982: 13). Carvalho (2007) defines an ideology as "a set of ideas and values that legitimate a program of action vis-à-vis a given social and political order" (2007: 1). She argues that ideology works as a powerful selection device in deciding what the relevant "facts" and who the authorized "agents of definition" are.

In the United States, neoliberalism is the "defining political economic paradigm of our time" (McChesney 1999). Neoliberalism privileges economic liberalization, free trade, open markets, privatization, and deregulation—all activities that advance the interests of extremely wealthy investors and large corporations (ibid). Yet McChesney argues that

"a generation of corporate financed public relations efforts has given these terms and ideas a near-sacred aura. As a result, these phrases and the claims they imply rarely require empirical defense, and are invoked to rationalize anything from lowering taxes on the wealthy and scrapping environmental regulations to dismantling public education and social welfare programs. Indeed, any activity that might interfere with corporate domination of society is automatically suspect because it would impede the workings of the free market, which is advanced as the only rational, fair, and democratic allocator of goods and services" (McChesney 1999: 40-41).

Carvalho (2005) found that the British quality press's analysis of the governance of climate change "remained within the broad ideological parameters of free-market capitalism and neoliberalism, avoiding a sustained critique of the possibility of constant economic growth and increasing consumption, and of the profound international injustices associated with the greenhouse effect" (Carvalho 2005: 21). Once an ideology like neoliberalism gains widespread acceptance, people come to see it as a representation of "how the world is" rather than one viewpoint among many possible ways of making 
sense of the world (Hall 1995). In other words, dominant ideologies attain hegemonic status and are rarely challenged (Gramsci 1971). The media plays a central role in ideological transmission.

\section{Political Economy of the Mass Media}

Herman and Chomsky (1988) argue that huge inequalities in wealth and resources allow elites to dominate the media and marginalize dissent. They employ a "propaganda model" to assess the mass media's performance and show that due to (1) centralized corporate control, (2) advertising as a primary income source, (3) reliance on elite sources for information, (4) "flak" as a means of disciplining the media, and (5) "anticommunism" as a national religion and control mechanism, the information that the public receives from the mass media is extensively filtered through the lens of corporate America. Journalistic norms further ensure coverage that serves the ends of corporate and government elites. The five elements of Herman and Chomsky's (1988) model as well as the concept of journalistic norms are discussed in more detail below.

\section{Corporate Control}

Beginning in the mid-1960s, large corporations with heavy investments in the fossil fuel industry (notably IBM, RCA, Raytheon, General Electric, and Westinghouse) suddenly began buying media companies. Their motivation was-stated succinctly by a Wall Street acquisition expert—“profitability and influence” (Bagdikian 2004). In 1984, fifty corporations controlled the market; by 1996, after the passage of the Telecommunications Act, the number was down to ten (Bagdikian 2004). Today, five 
corporations $^{2}$ control $90 \%$ of all media outlets (Bagdikian 2004). As media ownership has become increasingly centralized, a small group of media elites have gained the power to directly influence nearly all of the information and programming that reaches 300 million Americans. Despite the illusion of endless choice and information, what it is possible to choose between is predetermined by corporate elites (Nisbet \& Myers 2007). This is troubling because, according to the U.S. Supreme Court (1945), "One of the most vital of all general interests [is] the dissemination of news from as many different sources, and with as many different facets and colors as is possible. That interest... presupposes that right conclusions are more likely to be gathered out of a multitude of tongues, than through any kind of authoritative selection" (Gentzkow and Shapiro 2010).

The corporations that own the mass media are among the primary beneficiaries of neoliberal globalization (McChesney 2003). Approximately two-thirds of these firms are closely held or controlled by members of the originating family, who have a stake in the status quo by virtue of their wealth and position in society (Herman and Chomsky 1988). These individuals are able to exercise their power by establishing the aims of the company and choosing its top management. Furthermore, they have extensive links to the mainstream corporate community through their boards of directors (which are dominated by corporate and banking executives) and elite social experiences.

\section{The Role of Advertising}

With the corporate takeover of the media came a corresponding shift in the emphasis on profit. Advertisements became the major source of revenue for television,

\footnotetext{
${ }^{2}$ GE/NBC, Disney/ABC, Viacom/CBS, FOX/News Corporation, and AOL Time Warner
} 
radio, and newspapers, and the goal of each medium became to deliver the largest possible audience to advertisers. Bagdikian (2004) notes that while the reporting of news has always been a commercial enterprise, the corporate takeover of the media has resulted in higher levels of manipulation of news and a decreased sense of obligation to serve the noncommercial information needs of the public than ever before.

Advertisers are interested in attracting audiences with buying power, not audiences per se, which means that content that might be relevant or interesting to the less affluent will be de-emphasized or altogether absent (Herman and Chomsky 1988). This contradicts the assumption that the media choices are determined by audience preferences; it is advertiser preference that ultimately influences content. As Mander (1978) argues, advertisers need the audience to be in a "buying mood" when their ads are presented and therefore prefer light entertainment over serious content and analysis of public affairs. After all, an audience that is contemplating rising levels of inequality, war, and ecological crisis will not be very receptive to an advertisement for Coca-Cola. An audience that is being entertained with sports, celebrities, and humor, on the other hand, will be. The corporate owners' pursuit of ever-higher profit margins therefore results in news coverage and TV programs that suit the commercial needs of corporations and advertisers rather than the informational needs of citizens and consumers (Mander 1978). Since advertisers will rarely sponsor programs that criticize corporate activities, serious critiques are all but absent in the mass media.

Herman and Chomsky (1988) show that this has a significant impact on political attitudes and outcomes, noting that advertising served as a powerful mechanism to 
weaken the working class press in Great Britain between 1960 and 1967. Without advertiser support, working class newspapers ceased to be economically viable and were absorbed into establishment systems. This resulted in a dearth of alternative frameworks of analysis that contested dominant interests and led to the decline of the Labor party (and decreased political power for the working class). Clearly, a movement without mass media support faces grave odds.

\section{Reliance on Elites}

The story and "facts" that the media presents about an issue are in large part determined by the sources interviewed (Tuchman 1978). However, not all claims-makers have equal access to the mainstream media. Claims-makers are those who articulate and promote specific arguments and tend to realize benefits of some sort if those claims are accepted as true. Herman and Chomsky (1988) argue that economics encourages reporters to concentrate their resources where significant news usually occurs (e.g. the White House, Pentagon, and State Department). Corporations, trade groups, and other powerful institutions are also regular purveyors of stories deemed newsworthy. They turn out a large volume of material which meets the demands of news organizations and can be used at no cost. The public relations budgets of government branches and large corporations dwarf those of organizations with challenging views; these organizations, therefore, cannot compete with government and corporate elites in terms of getting their viewpoints across. In addition, the time constraints associated with producing daily news predisposes journalists towards elite sources that are easily accessible and already perceived to be trustworthy. Herman and Chomsky (1988) conclude that the 
bureaucracies of the powerful subsidize the mass media and gain special access by decreasing media corporations' costs.

As a result, Hall et al. (1978) showed that "official" sources tend to get privileged access to the news media and become 'primary definers' of key issues. For example, in mainstream press coverage of the Exxon Valdez oil spill, Smith (1993) finds that the majority (61 percent) of the sources consulted were corporate or government elites (i.e. representatives of the Alaska and federal governments and/or the oil industry). This illustrates the fact that unlike regular citizens or groups, elites can easily gain access to media outlets that will broadcast their views and policy preferences, often without critical examination or assessment (Parenti 1986). They are able to identify issues of importance and, through omission of information, rule out others. These issues are the ones the public comes to regard as significant (Iyengar 1991). This gives elites an agenda-setting power that regular citizens do not possess (Cohen 1963). They use this power to inundate the media with stories that foist a particular frame on the public or chase unwanted stories off the front pages (Herman and Chomsky 1988). Meanwhile, non-routine and critical sources must struggle for access, and are often avoided because they may offend journalists' primary elite sources. The media thereby elevates purveyors of the "official" view (i.e. the one that is functional for elite interests), making them the experts, while diminishing the perspectives of "the poor, the powerless, and the ideologically marginal" (Gans 1983: 182 in Widener and Gunter 2007). 


\section{Avoidance of Flak}

Media owners, executives, and journalists" desire to avoid "flak" further discourages criticism of powerful interests. Flak includes negative responses to media statements or programs, and may take the form of public statements or letters, petitions, lawsuits, boycotts, or bills introduced to Congress. The ability to produce flak is directly related to power, as only those individuals or groups with substantial power and resources are able to effectively produce it. The U.S. government is a major producer of flak, regularly "assailing, threatening, and 'correcting' the media, trying to contain any deviations from the established line" (Herman and Chomsky 1988: 28), as are corporations and corporate-supported institutions such as the American Legal Foundation, the Media Institute, the Center for Media and Public Affairs and Freedom House. For example, when the mainstream media reported on the systematic killing of Salvadoran civilians by the U.S.-supported military government of El Salvador in the early 1980s, Freedom House publicly denounced the media's “imbalanced” reporting (Herman and Chomsky 1988). The media therefore take care not to offend the constituencies likely to produce flak - that is to say, the U.S. government and powerful corporations. Direct interference by media owners and executives is often not necessary; rather, implicit pressure leads journalists to self-censor and write stories in ways that do not directly threaten corporate interests (Anderson 2009). While citizens could once rely on journalists to investigate corporate greed and malfeasance, corporations now own the newspapers and TV stations that employ the journalists. 


\section{Anticommunist Ideology}

The final component of Herman and Chomsky's (1988) propaganda model is the pervasive ideology of anticommunism. Communism has always been a threat to property owners, as it challenges the primacy of individual freedom, private property rights, laissez-faire government and free trade. As a result, the Soviet, Chinese, and Cuban revolutions, which aimed to socialize the means of production, were vehemently opposed by Western elites - and opposition to communism became a defining principle of Western ideology (Herman and Chomsky 1988).

The dominance of anticommunist ideology acts a control mechanism (Herman and Chomsky 1988), discouraging content that may be seen as "pro-Communist or insufficiently anti-Communist" and keeps liberals "constantly on the defensive in a cultural milieu in which anticommunism is the dominant religion" (p. 29). Liberal ideology is implicitly cast as deviant, while conservative ideology is presented as being in line with Western democratic ideals.

It is, of course, not the case that critiques of capitalist interests never appear in the mass media. The mass media does permit (and even encourage) debate and dissent, as long as it remains "within the system of presuppositions and principles that constitute an elite consensus" (Herman and Chomsky 1988). But the corporate-controlled media apparatus has the power to treat certain subjects briefly and unsympathetically while treating subjects favorable to the corporate ethic frequently and in depth (Bagdikian 2004). In other words, the version of the world that emerges is one that reflects the 
political and economic worldview of the most privileged segment of the population.

Parenti (1986) argues that the distortions of the press

"are not innocent errors, for they are not random; rather, they move in the same overall direction again and again, favoring management over labor, corporatism over anti-corporatism, the affluent over the poor, private enterprise over socialism, Whites over Blacks, males over females, officialdom over protestors, conventional politics over dissidence, anticommunism and arms-race over disarmament, national chauvinism over internationalism, U.S. dominance of the Third World over revolutionary or populist national change" (p. 8).

\section{Journalistic Norms}

Journalistic norms also impact the way that issues are covered in the news. First, the norms of balance and objectivity lead journalists to believe they must cover "both sides" of every story (Anderson 2009). Gitlin (1980) argues that powerful interests in technological controversies capitalize on the media's balancing norm to gain publicity for positions that do not pass muster in the scientific community, where empirical verification rather than "balance" is the standard for credibility. This practice has resulted in coverage of climate change that implies that the scientific community is split down the middle on its causes even though there is an overwhelming consensus on the anthropogenic causes of climate change, and allowed fringe skeptics to achieve parity with some of the most renowned experts in the field (McCright and Dunlap 2003). The need for a dramatic narrative exacerbates this trend, encouraging reporters to solicit statements from scientists holding the most extreme views regarding a scientific issue, regardless of the fact that the bulk of scientists hold positions between the extremes and 
may tend toward a consensus position (Freudenburg and Butte1 1999; Schneider 1993). This false dichotomy breeds confusion within the general public, resulting in policy inaction that favors powerful interests (McCright and Dunlap 2003).

Given James Hansen's conclusion that the Keystone XL pipeline would be "game over" for the climate, it is crucial that we understand what kind of information Americans have received about the project, the context in which the information is presented, who is consulted about the pipeline proposal, and what accounts for media framing choices. Although all of the theoretical perspectives discussed in this chapter have informed my thinking, I rely most heavily on Block's (1987) theory of state, Hall (1995) and Gramsci's (1971) notions of ideological hegemony and Herman and Chomsky's (1988) propaganda model to guide my analysis.

Theoretically, Herman and Chomsky's (1988) propaganda model suggests that television news coverage of any particular issue will favor corporate interests regardless of the facts. The first hypothesis of this research is, therefore, that the information television news stations provide about the Keystone XL pipeline proposal will largely fit the needs of TransCanada and other corporations for favorable coverage of fossil fuel production rather than the needs of citizens for accurate, critical information or environmental advocates for discussion of the harmful environmental impacts of the project.

Given the media's unwillingness to offend corporate sensibilities (Herman and Chomsky 1988), the second hypothesis of this study is that the context provided by television news broadcasts will favor corporate interests by emphasizing the economic 
concerns that the pipeline might address (i.e. jobs and gas prices) rather than environmental or social problems that it might create (i.e. oil spills or other health and safety concerns).

The third hypothesis of this study is that, following Herman and Chomsky (1988), a majority of the sources consulted about the pipeline will be individuals who occupy positions of power (i.e. corporate or government elites) rather than ordinary citizens or environmental advocates and that dissent will be marginalized. In addition, given Block's (1987) theory of state, when government representatives are consulted, the expectation is that they will tend to speak for the economic interests of elites and corporations.

Finally, in light of Hall (1995) and Gramsci's (1971) theories of ideology and Herman and Chomsky's (1988) propaganda model, the final hypothesis of this study is that the central frames employed by television news broadcasts will support rather than challenge neoliberal economic arrangements and the interests of corporate and government elites who benefit from them. 


\section{CHAPTER IV: METHODOLOGY}

In order to determine how the Keystone XL pipeline is presented to the American public on television news, I employ content analysis to identify manifest content (i.e. the surface content) and frame analysis to identify latent content (i.e. the underlying meaning). Content analysis allows for objective, systematic description of the information presented and has the advantage of reliability, while frame analysis allows for an assessment of the logics and ideologies that influence and motivate these presentations and has the advantage of validity. Babbie (2002) argues that whenever possible, researchers should use both methods. This chapter outlines this project's research design. I first describe the data collection process, including the data source(s) sample, and selection criteria. I then discuss the coding strategies that I employed and the strategies that informed my analysis.

\section{Data Collection}

Most Americans get the majority of their information from television news broadcasts (Morris 2005; National Science Foundation 2010; The Pew Research Center 2010). By comparison, newspapers are now primarily relied on by only 20 percent of the populace, and radio is utilized by a mere 6 percent. Although the internet is becoming increasingly important, only 22 percent of Americans currently use the internet as their

primary news source (National Science Foundation 2010). The data set for the study was therefore composed of 177 news segments on national network (ABC, CBS, and NBC) and cable (CNN, MSNBC, FOX) television stations. These stations were selected 
because their news programs garner significantly more viewers than any other sources in television news and are regarded as most representative of current television news coverage (Project for Excellence in Journalism 2006 in Boykoff 2007).

The network news programs on $\mathrm{ABC}, \mathrm{CBS}$ and $\mathrm{NBC}$ are by far the most watched sources of television news. In 2004, an average of 28.8 million viewers watched the three network evening newscasts each evening. The NBC Nightly News generates 11.2 million viewers, while $\mathrm{ABC}$ World News Tonight attracts 9.9 million and CBS Evening News garners 7.7 million (Project for Excellence in Journalism 2006 in Boykoff 2007). The audience share of cable broadcasts is much smaller, but has been increasing steadily. In 2004, 2.6 million viewers watched cable evening newscasts (a 6\% increase from 2003), where FOX captured 55\% of the market CNN held 30\% MSNBC controlled 15\% (Project for Excellence in Journalism 2006 in Boykoff 2007). The number of viewers of network evening news broadcasts was still approximately 11 times greater than that of cable viewers.

This research examines transcripts that appear on network and cable news stations between September 2008 and September 2012. This four year time period that corresponds to TransCanada's initial submission of the Keystone XL proposal 2008 and TransCanada's re-submission of its proposal in 2012. This time period allows for a variety of events, debates, and issues to be accounted for, including the initial pipeline proposal (2008), review by the State Department (2008-2011), controversy over the review process (2011), protests at the White House (2011), inclusion in the payroll tax cut extension debate (2011), and President Obama's decision to delay the project (2012). 
Transcripts of all stories on these six stations that mentioned the Keystone XL pipeline in the headline or body of the text were identified by searching for the keywords "Keystone pipeline" in Lexis Nexis. Within these parameters, I identified 54 network transcripts and 704 cable transcripts. All network transcripts were included in the sample, and a $20 \%$ sample of all cable transcripts was obtained by arranging all transcripts from each station chronologically and selecting every fifth transcript. All transcripts that devote at least one substantive sentence to the topic were analyzed. Duplicated and/or syndicated stories were identified and removed. The final sample consists of 50 network and 127 cable transcripts.

\section{Data Analysis}

Previous studies have shown that with respect to climate change, the mass media distorts scientific facts to a significant degree (Dispensa and Brulle 2003; Boykoff 2007; Feldman et al. 2011) and provides coverage that is informationally deficient (Boykoff and Boykoff 2004). With these studies in mind, I investigate the type of claims presented about the Keystone XL pipeline and whether claims about the pipeline are vetted. Furthermore, as previous studies show that media coverage of oil spills tend to fit the needs of corporate and government elites rather than the needs of citizens and environmental advocates, I explore the context in which the Keystone XL pipeline proposal is presented. In addition, since elites have been shown to dominate media coverage of other environmental issues (Molotch and Lester 1975; Daley and O'Neill 1991; Smith 1993) I analyze which sources shape the discourse about the Keystone XL 
pipeline in television news, and the political and economic forces that they represent. Finally, given the importance of news frames in shaping public opinion (Iyengar 1991; Page and Shapiro 1992; Hart 2011), I identify the dominant frames that are employed by television news broadcasts to discuss the Keystone XL pipeline proposal and the ideologies that inform them.

\section{Manifest Content}

According to Winett (1997), researchers should read each text at least three times. During the first reading, I familiarized myself with the text. During the second reading, I conducted a more systematic analysis and coded the manifest content of each story (i.e. claims made about the pipeline, issues mentioned in association with Keystone XL, and source(s) consulted). I created a coding sheet [see Appendix B] in order to keep track of the type of information included in each story. I first coded the explicit claims made about Keystone XL and sorted them into two categories: favorable and opposing. Common favorable claims included statements that Keystone XL would create jobs, reduce gas prices, or enhance U.S. energy independence or national security. Common opposing claims included statements that Keystone XL would result in environmental disaster or that there were environmental concerns about the project.

Next, in order to gain a sense of the context in which the project was presented, I recorded the issues mentioned during the segment in which Keystone $\mathrm{XL}$ appeared. For example, if Keystone XL was mentioned in a segment dealing with joblessness and unemployment rates, I recorded the number of times these issues were mentioned. The 
final issue categories included: jobs, gas prices, national interest, politics, the environment, alternative energy, and climate change.

Then, given the dominance of elite sources in media representations of oil spills, sources quoted or interviewed about Keystone XL were identified as representing one of the following categories: Government (politicians, officeholders, officials, and campaign managers); Business (executives, lawyers, or employees speaking on behalf of a company or commercial enterprise); Science (credentialed individuals with a relevant affiliation); Environment (individuals speaking on behalf of an environmental organization or environmental social movement); and Labor (union representatives or individuals speaking on behalf of a labor organization).

\section{Latent Content}

During the final reading, I employed frame analysis in order to identify dominant frames within texts. Gamson and Modigliani (1989) argue that every news story employs frames to organize meaning. Frames can be identified through the words, metaphors, exemplars, descriptions, arguments, and visual images that are used in a story or report (Van Gorp 2007). While claims-making focuses on observable behaviors and statements, the concept of framing invokes Lukes' (1974) notion of the third face of power, which, as opposed to pluralist notions of power (the first face) and agenda-setting power (the second face), deals with the power to manipulate the view of others (McCright and Dunlap 2000). The framing concept therefore "provides more leverage for understanding the underlying structures of power in which social problems discourse is embedded" (McCright and Dunlap 2000: 503). 
In order to identify frames, I utilized an inductive approach. Following Gamson and Lasche's (1983) frame matrix [see Appendix A], I identified key components (e.g. words, metaphors, catchphrases, and depictions) used in the story or report. Next, I examined the latent content of each segment, which includes consequences and appeals to principle. Following that, I noted recurring ideas, language, and images and other salient features. Finally, I looked across the texts to identify patterns and categories. I then collapsed these categories into themes. Taken together, these elements activate particular logics or values and signal a frame. 


\section{CHAPTER V: FINDINGS}

In this chapter I examine the way the Keystone XL pipeline was presented by the mainstream television news media by evaluating the type of information provided about the pipeline proposal, the context in which the pipeline is presented, the sources that are cited or consulted, and the way in which the story is framed. The chapter concludes with a summary of the findings.

\section{Type of Information Provided}

Although the search parameters began when Keystone XL was proposed in 2008, most news channels do not mention Keystone XL until November of 2011. This is illustrated by Figure 1 below. This means that during the period which Keystone XL was being evaluated and considered by the State Department, most news stations did not provide any information about the pipeline proposal to the public. Citizens who rely on network news for information were therefore excluded from participating in the conversation about Keystone XL until its fate had nearly been decided. By the time most heard about the pipeline on television news stations, the State Department was already preparing to approve it. Furthermore, charges of conflict of interest and improper political influence on the state department's review process are mentioned in only 3 out of 177 (less than $2 \%$ ) of all broadcasts. 
Figure 1: Television News Stories, 2008-2012

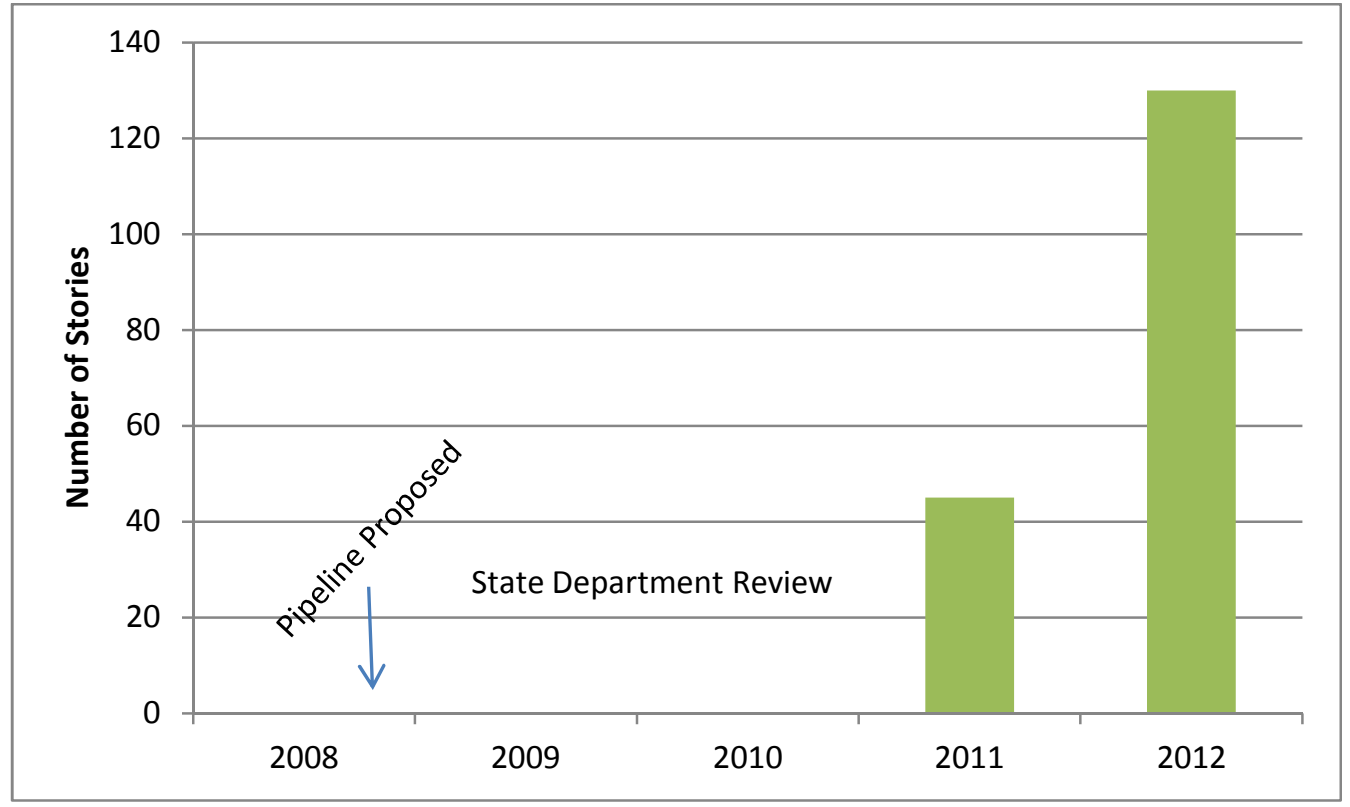

Figure 2: Television News Stories, 2011-2012

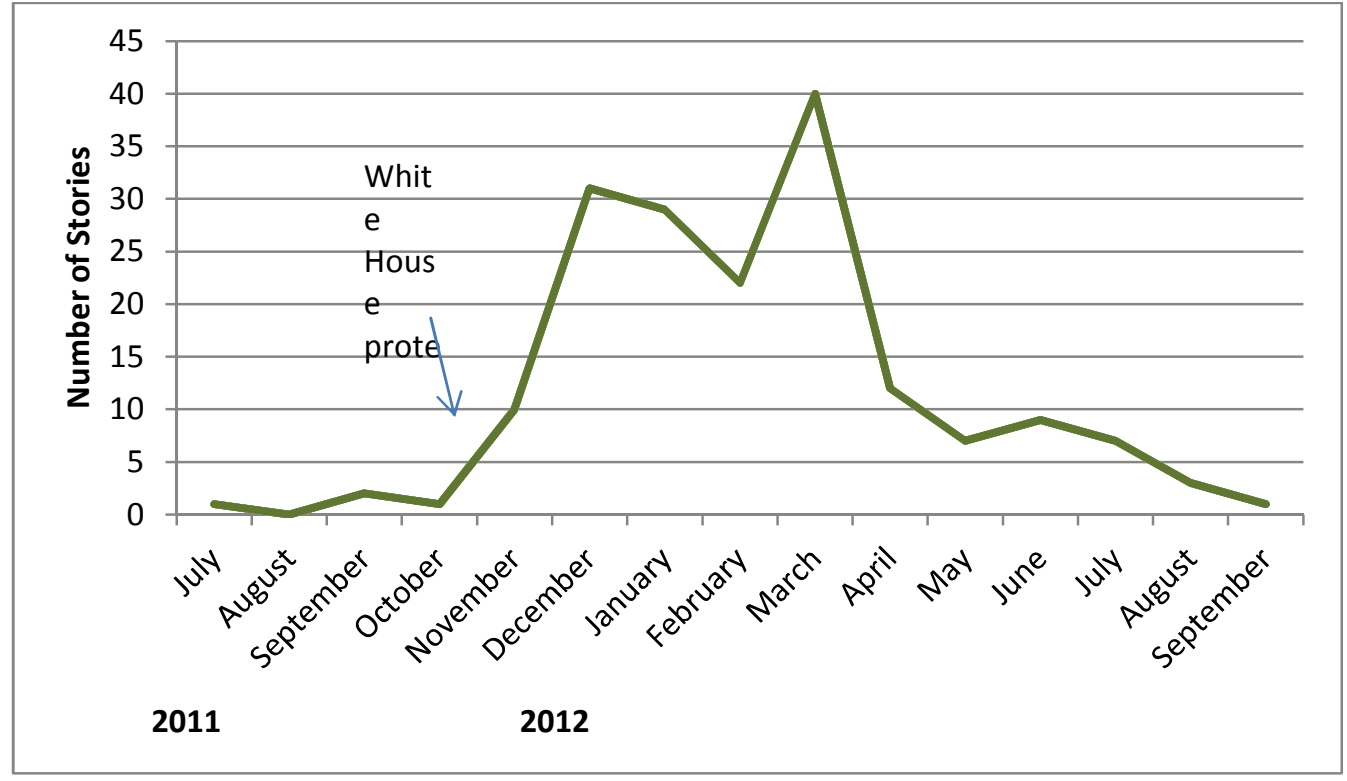


News coverage of the pipeline debate largely began in November 2011, when a large protest at the White House took place. However, very few broadcasts provided coverage of the protest itself. Viewers of most channels would have had very little idea that protests were even taking place—let alone what the protesters were actually upset about. Up until November 2011, Keystone XL had only been mentioned once or twice on some channels (and on other channels not at all), but was mentioned in 10 broadcasts during November of 2011. As shown in Figure 2, the number of news stories that discussed the pipeline rose dramatically in December 2011, when House Republicans included Keystone XL in the year-end payroll tax cut extension bill and the political battle over the fate of the project began. The number of stories began to decrease following President Obama's decision to delay the project, but rose again in March 2011 with the President's appearance at a pipeline construction site in Cushing, Oklahoma to declare that the Gulf Coast portion of the pipeline was a priority for his administration. Coverage of the pipeline declined sharply the following month, and reached preNovember 2011 levels by the summer of 2012 .

Network and cable channels allocated different amounts of time and detail to the pipeline proposal. Table 1 shows that on each of the network news channels (ABC, NBC, CBS) during the four-year period of analysis-i.e. well over a thousand broadcasts on each channel-20 or fewer broadcasts mentioned the Keystone XL pipeline. This lack of coverage is, in and of itself, notable. For comparison, on each of these channels, a preliminary search of Lexis Nexis returned an average of 150 broadcasts that devote airtime to the 2012 divorce of celebrities Katie Holmes and Tom Cruise. 


\section{Table 1: Broadcasts Mentioning Keystone XL}

\begin{tabular}{lc} 
Channel & Number of Broadcasts \\
$A B C$ & 15 \\
$N B C$ & 17 \\
CBS & 20 \\
MSNBC & 80 \\
CNN & 309 \\
FOX & 316 \\
Total & 759 \\
\hline
\end{tabular}

Cable news channels (MSNBC, CNN, FOX) provided more coverage of Keystone XL, with the population of broadcasts that mention the pipeline falling between 100 and 200. Network news broadcast segments that mentioned Keystone XL tended to be shorter, headline-style reports that were sometimes only a few sentences long. Cable news broadcasts tended to utilize discussion-based formats in which guests were interviewed, co-hosts debated an issue, and/or video clips from other sources were played. The presentation of Keystone XL on both network and cable stations is distinctly episodic; that is, news broadcasts present Keystone XL as an isolated development rather than situating it within the landscape of current energy consumption and production in the United States, existing pipelines and the concerns associated with them, or its role in the advancement of global climate change.

Across all stations, as illustrated by Figure 3, favorable claims about the pipeline were aired nearly four times as often as claims in opposition to the pipeline. Common favorable claims, as shown in the examples below, include statements that Keystone XL 
will create jobs, address high gas prices, and/or increase U.S. national security or energy independence.

Figure 3: Favorable and Opposing Claims, by Station

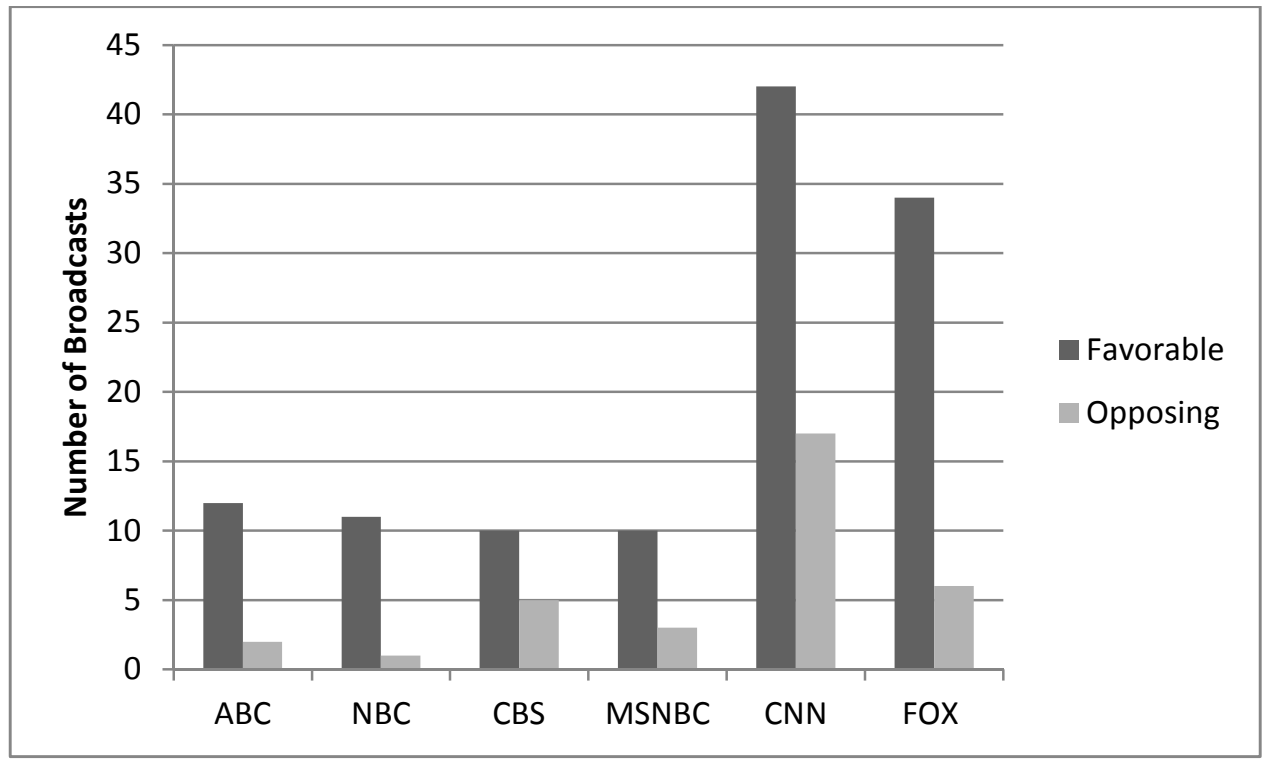

- Let's open up the Keystone pipeline to ... dramatically reduce our dependency on foreign oil. It creates jobs here in America. It lowers gas prices, increases supply. -ABC, April 1, 2012

- The Keystone pipeline would carry oil from Canada all the way down to the refineries along the Gulf of Mexico and create thousands of jobs.

-CBS, November 7, 2011

- We're introducing a stand-alone bill [in support of Keystone XL] . . to create jobs and good energy for our country.

-CNN, January 30, 2012

- Proponents argued Keystone XL would also have immediately created 20,000 direct jobs and another 320,000 jobs by 2015.

-FOX, January 18, 2012 
Viewers are repeatedly told that the project would create jobs, with estimates ranging from a few thousand to several hundred thousand jobs. These numbers are almost never questioned or challenged, nor are stakeholders asked to explain or defend how they arrived at these numbers. This is especially interesting given the State Department's (2011) conclusion that the pipeline would create no more than 6,000 temporary jobs, while Cornell University's Global Labor Institute estimated the number at closer to 2,000. A TransCanada executive stated that the number of permanent jobs created would only be in the hundreds (Cable News Network 2011). Cornell's Global Labor Institute (2011) also concluded that oil from the pipeline would not reach markets anytime soon (and would therefore not reduce gas prices) and that the crude oil routed to the Gulf Coast would be exported and would therefore not decrease US reliance on foreign oil. Yet these factually incorrect claims were presented over and over again with virtually no challenge.

While favorable claims about the pipeline cite tangible benefits like jobs and lower gas prices, opposing claims are often vague statements about "issues" or "environmental concerns" that have been raised about the pipeline, as the below excerpts illustrate.

- That part goes through the Nebraska Sandhills and there are some environmental concerns there.

-CNN, March 24, 2012

- Well, and issues were raised with the water source in Nebraska. The people of Nebraska are deeply concerned about that.

-FOX, March 25, 2012

Viewers are therefore told that there are "environmental concerns" or "risks" 
associated with the pipeline, but are left with little understanding of what those concerns and risks actually entail. Furthermore, details about the social and environmental consequences of the pipeline, including displacement and harm to indigenous populations, water waste and pollution during the extraction process, strip mining of pristine forest lands, oil spills, and massive amounts of greenhouse gases that would be released in the extraction of tar sands are conspicuously absent from nearly every broadcast. Also absent from nearly every television news broadcast is any reference to the charges of conflict of interest and improper political influence on the State Department's review process.

When favorable statements are presented, they are often presented on their own (i.e. without any opposing statements). This occurs in $51 \%$ of all broadcasts. By contrast, only $3 \%$ of the broadcasts presented opposing statements on their own (i.e. without any favorable statements). Favorable claims are usually presented as factual statements that are beyond debate, while opposing claims are presented as mere theoretical possibilities. In the excerpt below, for example, the anchor states that the pipeline would create "a lot" of jobs, but the aquifer "could be" contaminated if there was a leak in the line.

- [The Keystone XL pipeline] would be 1,700 miles, snaking through 6 states, from Canada to Texas, carrying oil, creating a lot of jobs. The problem, the underground water in Nebraska, which could be contaminated if there was a leak in the line. -ABC, January 18, 2012

The television news media's presentation of relative certainty about the large number of jobs the pipeline will create combined with apparent uncertainty about the likelihood of oil spills and contamination is telling, given TransCanada's own admission 
that the pipeline will result in only a few hundred permanent jobs and the State Department's (2011) determination that even if all safety precautions are followed, oil spills are likely. This shows that even when accurate, factual information is widely available and accessible to journalists, misinformation and false claims that fit the needs of business and government elites will still be regularly presented, often without challenge.

\section{Context of Presentation}

Explicit claims about the Keystone XL pipeline are not the only type of information that television news broadcasts provide. The context in which the pipeline proposal is presented also conveys information to viewers about the importance of the project, what the pipeline represents, and how Keystone XL should be understood.

On network and cable television news broadcasts that mention Keystone XL, the pipeline is rarely the focus of the segment. More often, the pipeline project is embedded in a discussion of unemployment rates, gas prices, or the economy. Some segments begin with a statement about rising gas prices, and in the course of the conversation, Keystone $\mathrm{XL}$ is mentioned as one way to mitigate high fuel costs. In others, a politician (e.g. Mitt Romney in the excerpt below) connects the pipeline to improving economic prospects for Americans.

- Another issue front and center in this year's campaign, the price of gas and President Obama`s energy policy. Mister Obama has taken some heat for his decision to block part of the Keystone pipeline project.

-CBS, March 23, 2012 
- $\quad$ MITT ROMNEY: I know what it takes to put people to work, to bring more jobs and better wages. First, I'm going to take full advantage of our energy resources and I'll approve the Keystone Pipeline from Canada. Low cost, plentiful coal, natural gas, oil, and renewables will bring over a million manufacturing jobs back to the United States. -CNN, July 11, 2012

\section{Table 2: Issue Mentions}

\begin{tabular}{lcc}
\hline & Count & Percent of Total \\
Gas Prices & 571 & 31.2 \\
Jobs & 512 & 28.0 \\
Energy Independence & 477 & 26.1 \\
The Environment & 125 & 6.8 \\
Alternative Energy & 102 & 5.6 \\
Protest & 24 & 1.3 \\
Climate Change & 20 & 1.1 \\
Total & 1831 & 100.0 \\
& & \\
\hline
\end{tabular}

No broadcast began with a conversation about the environment, alternative energy sources or climate change. This means that the pipeline is almost always presented against the backdrop of economics or national self-determination and never within the context protecting and preserving the natural world, the health and safety of communities or the looming threat of climate change. While these issues are occasionally mentioned, they are dwarfed by discussion of jobs, gas prices, and energy independence. Table 2 summarizes this trend, indicating the number of times each issue is mentioned in a segment that also mentions the Keystone XL pipeline. On average, jobs, gas prices, and energy independence are each mentioned about four times as often as the environment or fossil fuel alternatives and more than 20 times as often as the protests surrounding the pipeline or climate change. 
However, perhaps most significantly, more than two-thirds (69\%) of the broadcasts do not mention any environmental issues associated with the pipeline at all. Moreover, even when "environmental issues" or "environmental concerns" are mentioned, details about what these concerns entail or how they might affect ecosystems and human communities are usually absent. This is significant because, as Iyengar (1991) notes, the themes and issues repeated on television news are the ones that become viewers' priorities. When the news media focuses on gas prices, jobs, and energy independence, viewers receive the message that these topics are important, while those that are not mentioned (e.g. the environment, health and safety, indigenous rights, climate change) are not. Figure 4, a weighted visual design created with the Wordle ${ }^{\mathrm{TM}}$ application, illustrates this concept.

Figure 4: Prominent Ideas Featured in Keystone XL Segments

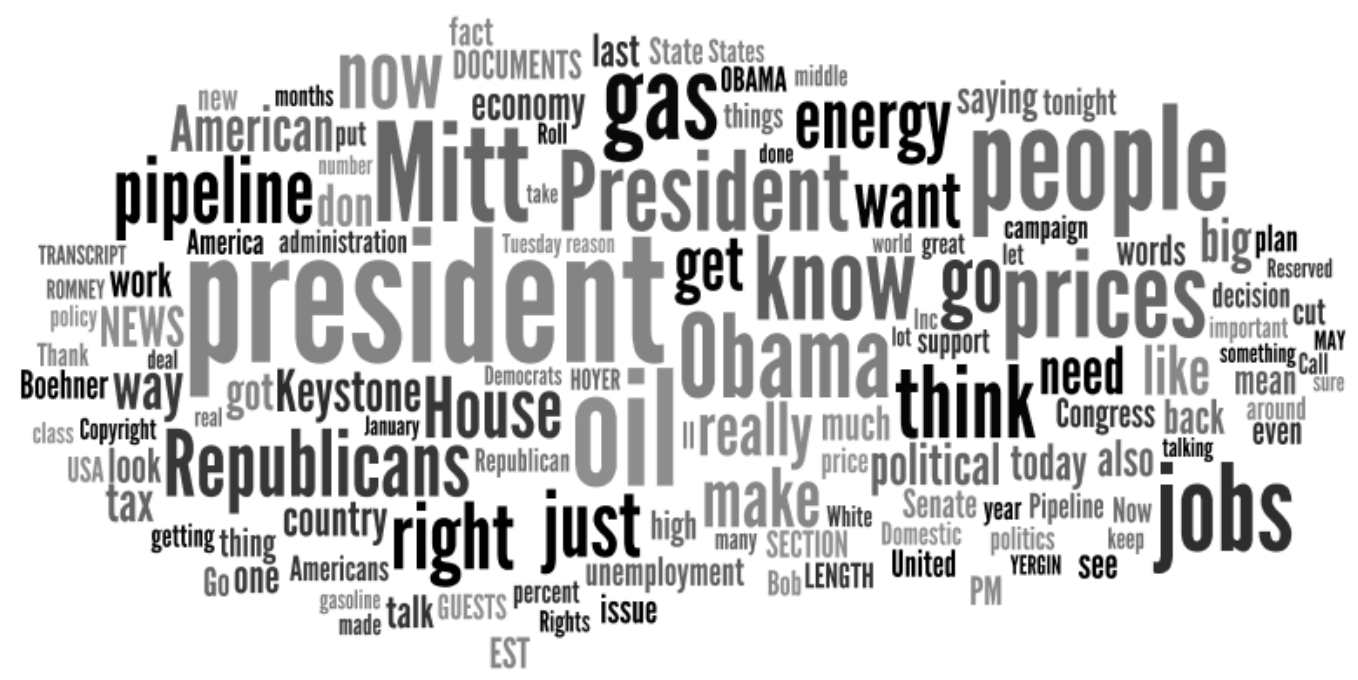


The Wordle ${ }^{\mathrm{TM}}$ application uses an algorithm to search user-provided text and presents the words that occur most frequently in the largest font. I entered the full text of all broadcasts in the sample, and found that the most prominent words in these broadcasts include: "president," “oil," “gas," “jobs," "prices," "Mitt [Romney]," “Obama," "pipeline," "Republicans," and "energy." Notably, the words “environment," "safety," "health," "carbon emissions," "climate change," "oil spill” and "alternatives" do not appear in Figure 4 at all—illustrating how small a role they play in to the overall conversation about Keystone XL that is taking place on television news.

\section{Who Speaks?}

News is jointly created by stakeholders who promote their agendas to media representatives and by media representatives and owners who decide which stories will be covered, and in what manner (Gamson and Modigliani 1989). The outcome of this process determines what type of information the public receives about important issues. A central element of the narrative about the pipeline, therefore, comes from the sources consulted about it. On television news broadcasts, this study finds that discussion about the pipeline was significantly shaped by state managers, as described by Block (1987). Table 3 shows that of all the stakeholders interviewed or quoted, 120 were government or business representatives (107 and 13 respectively), while only 8 were environmental advocates. This means that government and business representatives were consulted 15 times as often as environmental advocates. Government representatives include members of the U.S. Congress, state governors, White House or State Department officials, 
President Obama, political campaign representatives, and candidates in the 2012 presidential elections, while business representatives include CEO's of major corporations like TransCanada and Shell Oil and organizations representing them, including the American Petroleum Institute, the Institute for Energy Research and the American Energy Alliance. Environmental advocates largely include those speaking on behalf of the Natural Resources Defense Council and Friends of the Earth.

\section{Table 3: Sources Consulted}

\begin{tabular}{lrr} 
Government/Business & 120 & 82.3 \\
Business & 13 & 10.0 \\
Environment & 8 & 6.2 \\
Labor & 2 & 1.5 \\
Science & 0 & 0.0 \\
Total & 130 & 100.0 \\
\hline
\end{tabular}

Among state managers, Republicans were consulted about three times as often as Democrats. Prominent Republican sources included Mitt Romney, Newt Gingrich, Paul Ryan, and John Boehner-all of whom discussed the pipeline in positive terms and repeatedly stated that the Keystone XL pipeline would create jobs, decrease gas prices, and improve U.S. national security and energy independence. They also stated that by delaying the pipeline decision, President Obama had "killed jobs."

- GINGRICH: I would like to campaign this fall as a paycheck president, offering the American people a program to create jobs. He killed jobs as recently as last week with the Keystone pipeline decision.

-ABC, January 29, 2012 
- SANTORUM: It has nothing to do with what's best for the overall environment. It certainly has nothing to do with the national security of our country by being more dependent upon very dangerous areas of the world that allow the speculative price for oil to go up. All of this is the president's fault.

-NBC, March 11, 2012

- ROMNEY: Amazingly, he rejected the Keystone pipeline. I will approve it . . . [President Obama] has. ... stalled domestic energy production. I'm going to open up our lands for development so we can finally get the energy we need at a price we can afford. -MSNBC, March 6, 2012

- ANCHOR: The president blocked the \$7 billion plan temporarily Wednesday, saying more environmental studies were needed. House Speaker John Boehner accused the president of destroying tens of thousands of jobs.

-NBC, January 19, 2012

Among Democrats, the most prominent sources included President Obama, presidential advisors, and federal officials. These sources tended to discuss the pipeline in mild, neutral terms, stating that more time was needed to conduct a thorough environmental review.

- PRESIDENT OBAMA: To be extra careful that the construction of the pipeline in an area like that wouldn't put the health and safety of the American people at risk, our experts said we needed a certain amount of time to review the project.

-CNN, March 22, 2012

- DAVID AXELROD, PRESIDENTIAL ADVISOR: The State Department said they need more time to evaluate the project and all of its implications, including what it would mean for the water aquifers in Nebraska.

-CBS, March 18, 2012

When Democratic members of Congress were consulted, some supported the White House's neutral position, but, as evidenced by the quotes below, most voiced their support for pipeline construction. Much like Republican members of Congress, Democrats criticized President Obama's decision and tied the Keystone XL pipeline 
proposal to the well-being of the economy. No Democratic members of Congress voiced an opinion in opposition to the pipeline.

- REP. JASON ALTMIRE (D): There's a lot of Democrats in Congress that would like to get [the pipeline] done. I'm very disappointed in the decision that has been made. And I think it is a very bad decision for the country.

-FOX, January 20, 2012

- SEN. MARK BEGICH (D): So I think the president made the wrong decision here. I think the Keystone pipeline is a good jobs opportunity.

-NBC, January 18, 2012

- SEN. CHUCK SCHUMER (D): No Keystone Pipeline, no drilling in the gulf. At the end of the day, the economy is not doing well because of his politics.

-ABC, March 11, 2012

Business representatives, too, were supportive of the project, and argued that the

pipeline would create jobs, boost the economy, and improve U.S. national security, as

seen in the following excerpts.

- MARVIN ODUM (PRESIDENT OF SHELL OIL): If we really want more dollars flowing into the federal government to help with the deficit and so forth, and if we want more income taxes flowing in, the way to do that is to produce more energy in this country. And so the question that the Congress and that the President ought to be asking themselves is, how do we incentivize more production.

-CBS, March 30, 2012

- ALEX POURBAIX (TRANSCANADA CORP): When you boil down the debate on this project, I believe it comes down to a simple question for Americans: do they want secure, stable oil from a friendly neighbor in Canada? Or do they want to continue to import high-priced conflict oil from unfriendly regions such as the Middle East or Venezuela? -CNN, December 15, 2011

- JACK GERARD (AMERICAN PETROLEUM INSTITUTE): Your approval of the Keystone XL Pipeline will almost immediately create 20,000 new American jobs here in The United States. There are over 2,400 U.S. companies that are currently involved with the development of oil sands from 49 different states.

-FOX, October 7, 2011 
Environmental advocates represented only 8 out of $130(6 \%)$ of the sources consulted about the pipeline. When consulted, they emphasized the argument that tar sands oil is dirty, that it contributes to climate change, and that the pipeline is unsafe.

- SUSAN CASEY-LEFKOWITZ (NATURAL RESOURCES DEFENSE COUNCIL): Is the growth going to be in clean energy or is the growth going to be in dirty energy? Are we going to be moving forward or backwards in terms of our energy needs? And will we look at the damage that climate change is doing every day already in the United States in violent storms and floods and droughts and hurricanes? I think the only answer is that we need to be moving forward with clean energy. We don't need the additional tar sands that would come in a new pipeline.

-CNN, April 2, 2012

- BOB DEANS (NATURAL RESOURCES DEFENSE COUNCIL): We re going to take the dirtiest oil in the planet, run it through the heartland of America, through the bread basket of this country, the granary of the world, and put at risk 260,000 farmers, ranchers, croplands, waters?

-MSNBC, November 152011

In every instance that an environmental advocate was consulted, business or government representatives were also consulted during the same broadcast. However, this norm of "balance" was not observed when business or government representatives were consulted; in $44 \%$ of the broadcasts, business and government representatives were allowed to speak without critique or challenge of any kind. Only two broadcasts out of 177 quoted a labor representative, while none quoted or interviewed an independent scientist about the potential environmental impacts of the pipeline.

It is to be expected that business representatives would favor proposals like Keystone XL, which facilitate and encourage private investment and are in line with neoliberal principles. However, Block (1987) notes that since current political and economic arrangements are the basis of their power, state managers (both Republican and 
Democrat) also tend to favor the interests of capital—as illustrated by the following excerpt, in which a U.S. Congressional Democrat advocates for TransCanada's plan to build the pipeline through the United States.

- REP. JASON ALTMIRE (D): We re talking about a $\$ 7$ billion private investment in America, tens of thousands of jobs. And this pipeline is going to get built either way. That is the thing. The Canadians are either going to build it to the south, to our Gulf Coast, creating American jobs, or they are going to go west to the Canadian coast, which is going to lead to further west exporting that oil off to Canada -- or to China, and we see no benefit from that.

-FOX, January 20, 2012

In line with previous studies (Molotch and Lester 1975; Daley and O’Neill 1991;

Smith 1993), this research finds that in mainstream media representations of

environmental issues, elites with primary interests in neoliberal capitalism and minimal

regulation are able to dominate news discourse. Business and government representatives

effectively link the Keystone XL pipeline to the growth of the U.S. economy and the well-being of American citizens. These individuals, in turn, have a significant impact on the news frames that are employed to discuss issues covered in the news.

\section{Frames}

The way an issue is framed in the news can profoundly influence public opinion and eventual outcomes (Iyengar 1991; Page and Shapiro 1987; 1992). From an analysis of the data, three main frames emerged: American Interest, Political Chess, and Protect \& Preserve. Most stories contained multiple frames; however, as shown in Table 4, the American Interest frame is clearly dominant. 


\begin{tabular}{|c|c|c|c|}
\hline Frame & Implication & Catch Phrases & Frequency \\
\hline $\begin{array}{l}\text { American } \\
\text { Interest }\end{array}$ & $\begin{array}{l}\text { The Keystone XL pipeline } \\
\text { will solve problems faced } \\
\text { by American workers and } \\
\text { consumers and advance } \\
\text { U.S. political and } \\
\text { economic interests. }\end{array}$ & $\begin{array}{l}\text { "Pain at the pump" } \\
\text { "Obama killed jobs" } \\
\text { "energy independence" }\end{array}$ & $83 \%$ \\
\hline $\begin{array}{l}\text { Political } \\
\text { Chess }\end{array}$ & $\begin{array}{l}\text { The Keystone XL pipeline } \\
\text { is a pawn in a game of } \\
\text { political strategy. }\end{array}$ & $\begin{array}{l}\text { "political points" } \\
\text { "playing politics" } \\
\text { "after the election" }\end{array}$ & $50 \%$ \\
\hline $\begin{array}{l}\text { Protect \& } \\
\text { Preserve }\end{array}$ & $\begin{array}{l}\text { The Keystone XL pipeline } \\
\text { poses a threat to humans } \\
\text { and the environment. }\end{array}$ & $\begin{array}{l}\text { "dirty oil" } \\
\text { "oil spills" } \\
\text { "environmental disaster" }\end{array}$ & $14 \%$ \\
\hline
\end{tabular}

\section{American Interest}

The most common frame, appearing in $83 \%$ of television news broadcasts, was American Interest. Proponents of this frame imply that increased oil production will solve problems faced by American workers and consumers and advance U.S. political and economic interests. Proponents suggest that high gas prices, unemployment rates, and dependence on Middle Eastern countries for oil are the issues that are or should be at the forefront of every American's mind. Common catch phrases include "pain at the pump" (a reference to high gas prices) and "Obama killed jobs" (by delaying his decision on the pipeline). Proponents imply that "\$4 a gallon gasoline" is a "crisis" that hurts American families, and argue that if more oil is available, prices will decrease and the "crisis" will be solved. The following excerpts show how the Keystone XL pipeline is also presented 
as a solution for jobless Americans, with proponents arguing that it could be a "lifeline" for the unemployed. Proponents of this frame also argue that by producing more oil at home, America would have a more secure supply and would therefore be less reliant on foreign oil. They state that if the United States does not approve the pipeline, the oil will "go to China" implying that someone is going to use the oil no matter what, and it should be the United States. Furthermore, proponents use appeals to patriotism to link the growth of the U.S. economy to the well-being of American citizens and suggest that a failure to support Keystone $\mathrm{XL}$ is a vote against American jobs, energy, and security, as exemplified by the following excerpts.

- REP. PAUL RYAN: -- coal, oil, gas, fracking, nuclear, renewables, all of the above. Stop shipping our jobs overseas. Stop sending our money overseas. Create jobs here. Use our own energy. That creates jobs. If we get a good energy policy, we get people off of the unemployment line and back to jobs working on things like the Keystone Pipeline. -CNN, August 21, 2012

- NEWT GINGRICH: So what I can guarantee you is the Obama program has higher prices, more dependency on the Middle East, more vulnerability to Saudi Arabia and Iraq and Iran; exactly the wrong direction ...

RICK SANTORUM: All sorts of opportunities for us to be more energy independent. And what does he say? No, Canada, you build the pipeline to the West Coast and send that oil to China.

-CBS, February 19, 2012

- SEN. ROY BLUNT: The Keystone pipeline is a big thing if it could happen. The shortest path to more American jobs is more American energy and more jobs that relate to American energy. The Keystone pipeline is 20,000 [jobs] without a single tax dollar involved.

-CNN, December 18, 2011

Concerns about the pipeline are presented as minor complications rather than fundamental questions about the ethics, wisdom, or sustainability of building a pipeline 
through sensitive lands and water sources and/or further investment in tar sands oil production, as shown below.

- We are changing the route slightly. But the old route that was proposed and the State Department said generally was $O K$ was through the most environmentally sensitive -going through the most environmentally sensitive portion of Nebraska called the Sandhills. And we are just going to move it a few miles to the east through less environmentally sensitive areas.

-FOX, January 19, 2012

The American Interest frame relies on neoliberal solutions to social and economic problems (e.g. dispensing with environmental regulations and the growth of private industry to create jobs and reduce commodity prices). The frame suggests that "the economy," understood in terms of economic growth, should dictate environmental policy rather than rational democratic planning processes and/or concern for the health and safety of ecosystems and human communities.

\section{Political Chess}

The second frame, Political Chess, is observed in $61 \%$ of all broadcasts and usually appears in conjunction with American Interest. Proponents of this frame suggest that the Keystone XL pipeline is merely a pawn in a game being played by elite political actors and imply that decisions about natural resources are only marginally relevant to Americans' lives. Common catch phrases include reference to the "political points" that President Obama is trying to score and the charge that President Obama or Congressional Republicans are "playing politics" with the pipeline decision. They imply that delaying the project to allow more time for environmental review is a political ploy, and the debate 
over the pipeline is just another stalemate between Republicans and President Obama, as evidenced by the following quotes.

- "[The pipeline decision] was postponed by the Obama administration many say to avoid an election year fight."

-MSNBC, November 15, 2011

- "Now that environmental debate is all political. The president says the Republicans have not given him enough time, but Republicans say he has chosen the environment over the economy."

-CBS, January 18, 2012

This frame does not provide space for the merits and drawbacks of Keystone XL to be discussed, nor does it suggest a role for citizens in the debate; instead, proponents abstract the Keystone XL pipeline from the larger social and environmental context in order to focus is on elite political actors, their tactical positions on the pipeline, and what they hope to achieve politically by promoting or opposing the pipeline. The central implications of this frame are that decisions about natural resources and energy policy will be made by self-interested politicians and bureaucrats rather than politically engaged citizens, and that the Keystone XL pipeline decision is a petty political squabble rather than a fundamental debate about whether, given what we know about global climate change, the history of oil pipelines, and the particular dangers associated with the this project, the United States should expand its investment in fossil fuels.

\section{Protect \& Preserve}

The final frame, Protect \& Preserve, is found in $14 \%$ of all broadcasts.

Proponents of this frame argue that tar sands oil is dirty and that oil spills are inevitable. 
Common catch phrases, as shown in the quotes below, include reference to dirty oil, oil spills and "environmental disaster."

- Then we we're going to take the dirtiest oil in the planet, run it through the heartland of America, through the bread basket of this country, the granary of the world, and put at risk 260,000 farmers, ranchers, croplands, waters? Just doesn 't make sense for the country.

-MSNBC, November 15, 2011

- $\quad$ The Keystone pipeline would carry oil from Canada all the way down to the refineries along the Gulf of Mexico and create thousands of jobs. Opponents fear an environmental disaster. They want President Obama to block the plan. -CBS, November 7, 2011

The implication is that oil pipelines inherently pose a threat to ecosystems and human communities. Proponents suggest that building the Keystone XL pipeline will put crucial resources (e.g. water, farmland) and human communities at risk. This frame employs the logic of mainstream reform environmentalism, which links human health and survival to environmental conditions (Brulle 2009). This perspective emphasizes that nature has a delicate balance, and since humans are part of this delicate balance, are vulnerable to disturbances in the ecosystem (Brulle 2009). The implicit conclusion is that the United States must decrease its reliance on fossil fuels and pursue alternative energy solutions. However, the main environmental critique of the pipeline (that it would be "game over" for the climate), is not included in this frame, which builds on McCright and Dunlap's (2003) work by showing that the non-problematicity of climate change has been so successfully established that it does not factor in to the media's discussion of the Keystone XL pipeline at all. This frame also fails to mention that the environmental 
hazards created by the pipeline would not be shared equally, but disproportionately borne by low-income, minority, and indigenous communities. Finally, it is important to note that this frame is usually presented in conjunction with the American Interest frame, which is almost always presented first and which occupies dramatically more time and space within each broadcast than Protect \& Preserve. This echoes the work of Widener and Gunter (2007), who found that dissenting frames are often used by the mass media to create an image of balance and objectivity rather than to actually present an opposing perspective.

\section{Summary of Findings}

This research finds that the television news media failed to provide timely information about the Keystone XL pipeline proposal, disproportionately presented favorable claims about the proposal, and failed to vet these claims for accuracy. Discussion of jobs, high gas prices, and energy independence dominate the conversation about the pipeline proposal, while environmental concerns are marginalized or ignored. Furthermore, government and business elites are able to dominate news discourse, while environmental advocates are relegated to the periphery. Finally, the dominance of the American Interest frame indicates that a neoliberal worldview, which promotes growth without limits, scrapping environmental regulations, and private industry as a solution to structural problems like unemployment, is disproportionately presented in the news. 


\section{CHAPTER VI: DISCUSSION AND CONCLUSION}

This thesis sought to understand the information Americans received about the Keystone XL pipeline from the television news media, and what the relationship between news coverage of this issue and the political economy of the mass media might be. As Herman and Chomsky (1988) argue, a basic tenet of democracy is that the media are committed to discovering and reporting the truth and do not merely reflect the world as the powerful wish it to be perceived. All societies, if they are to be free, need a media system that acts as "a rigorous watchdog of those in power, can ferret out truth from lies, and can present a wide range of informed positions on the important issues of the day" (McChesney 2003: 299). This study shows that in its coverage of the Keystone XL pipeline debate, the television news media fell far short of these democratic standards. In this chapter, I will revisit the four main research questions posed by this thesis and interpret the findings in light of the initial aims of the study.

\section{Fact and Fiction}

The first research question posed by this study asks: what kind of information is being provided about the Keystone XL pipeline proposal? The theoretical expectation was that the information presented would largely serve the needs of corporations (Herman and Chomsky 1988) rather than the interests of citizens and environmental advocates. Findings indicate that the media failed to inform viewers about the proposal while it was being developed by TransCanada and evaluated by the State Department, which allowed business and government elites to put the project in motion without 
question or challenge from citizens or environmental advocates. When the news media finally did cover the pipeline proposal in late 2011, information about charges of conflict of interest and improper political influence on the State Department's review process were absent. Viewers were therefore not provided with the full range of available information at best, and at worst were intentionally misled—severely restricting democratic participation in the debate over the pipeline.

In addition, despite the widespread availability of research reports concluding that there were serious concerns associated with the pipeline, more than two-thirds of all broadcasts failed to mention that there were any concerns associated with the pipeline. Of those that did mention that there were concerns associated with the pipeline, very few provided details about what these concerns might entail. This, in combination with television news' disproportionate presentation of favorable claims about the pipeline effectively encouraged viewers to support pipeline construction and the economic interests of elites who will benefit from it. This is especially troubling given the fact that the only independent study of the pipeline to date showed these favorable claims (about jobs, gas prices, and energy independence) were exaggerated or false (Cornell Global Labor Institute 2011).

Access to accurate, timely information is the foundation of a functioning democratic society. By failing to provide timely information about the pipeline proposal, transmit key facts, and vet claims made about the pipeline the television news media created a severe deficiency of knowledge among the viewing public and left audiences to form their opinions of the project based on selective or false information that favored 
corporate interests. These findings support the theoretical expectations of this research and are in line with Herman and Chomsky's (1988) conclusion that the information provided by the mainstream media will largely fit the needs of corporate America.

\section{Bias over Balance}

The second research question asks: what is the context in which the Keystone XL pipeline proposal is presented? Theoretically, the expectation is that, given the media's unwillingness to offend corporate sensibilities, television news broadcasts will emphasize economic rather than environmental or social concerns. The empirical results of this study show that the issues most often discussed in association with the pipeline were unemployment, rising gas prices, and energy independence, which, especially coupled with the absence of discussion about environmental considerations and climate change, makes Keystone XL seems like a logical solution to these economic issues as well as a beacon of hope for struggling Americans. When discussion of environmental and social problems is muted while mention of jobs, lower prices, and national security is prominent, television news stations effectively tell audiences that environmental and social concerns are irrelevant—which is significant in light of Page and Shapiro's (1982; 1997) findings that bias toward one perspective in news coverage corresponds with increased public support for that viewpoint. Ultimately, viewers are provided with little basis for understanding the environmental and ultimately social threats posed by Keystone XL and are encouraged to support pipeline construction for reasons of economic and national security rather than imagine alternatives that are more conducive 
to the health of the planet and its inhabitants. The theoretical expectation that the context provided by the television news media's presentation of the Keystone XL pipeline would serve the interests of corporations is supported by my findings.

\section{Elites Shape the Discourse}

The third research question posed by this study asks: who shapes the discourse about the Keystone XL pipeline proposal, and what political and economic interests do they represent? The theoretical expectation was that, as in previous studies of media coverage of environmental issues (Molotch and Lester 1975; Daley and O’Neill 1991; Smith 1993), elites would be consulted far more often than regular citizens or environmental advocates and that dissent would be marginalized. Empirical results indicate that, far from keeping tabs on powerful government elites, the network news media relied upon business representatives and state managers as sources of information on the pipeline in $92 \%$ of their broadcasts and failed to examine or analyze these representatives' claims. Environmental advocates were consulted only $6 \%$ of the time. Consistent with previous research, this study shows that elites with primary interests in neoliberal economics are able to dominate news discourse. Furthermore, the similarities in business and government elites' arguments and levels of support for the Keystone XL pipeline lends support to Block's (1987) argument that as capitalist economies are based on the private investment decisions of capitalists, state managers tend to enact policies that facilitate and encourage private investment even if capitalists make no overt demands that they do so. Government elites by and large advocated for the pipeline in much the 
same way that CEOs and representatives of business did. While the economic benefits of pipeline construction would largely accrue to elites, this was not acknowledged or discussed in television news broadcasts. Instead, business and government successfully promoted an interpretation of the project that equates the project with the interests with the interests of ordinary Americans (e.g. jobs, lower gas prices, national security).

A watchdog press is crucial to alerting citizens to the activities of power; without it, citizens remain unaware of critical information needed to inform their opinions. Television news' overreliance on business and government sources, failure to present alternative perspectives on Keystone XL, and failure to provide adequate airtime for opposing arguments means that the public is not being provided with the whole story about issues of social and environmental import. These findings are in line with the theoretical expectations of this work and the conclusions of Herman and Chomsky (1988), who argue that media bias toward business and government elites allows dominant interests to remain unchallenged.

\section{Neoliberal Frames}

The final question posed by this research asks: what are the frames employed to discuss the pipeline proposal, and what is the relationship between these frames and the political economy of the mass media? The theoretical expectation was that the dominant frames would support rather than challenge current political and economic arrangements. Empirical results highlight the predominance of the American Interest frame and indicate a bias toward neoliberal ideology in mainstream television news. Echoing the findings of 
Carvalho (2005), discussions of the pipeline stayed within the parameters of neoliberal capitalism and did not challenge the current political or economic order, which places economic concerns above and in opposition to environmental and social considerations. The television news media therefore presents the Keystone XL pipeline in such a way that the status quo (i.e. including investment in fossil fuels) is supported and maintained. By presenting jobs, gas prices, and national security as the main problems faced by Americans, and employing neoliberal ideology to interpret these problems, television news outlets lead viewers to the conclusion that regulation—especially environmental regulation—is bad, counterproductive, naïve, or just bad policy. This supports Herman and Chomsky's (1988) argument that the political economy of the mainstream media ensures that it will favor the interests of the powerful, who have primary interests in the neoliberal order and the continuation of carbon-based economies.

The challenging frame, Protect \& Preserve, appeared in a minority of the news broadcasts and was accorded dramatically less time and space within each transcript than American Interest or Political Chess. This calls to mind Bagdikian's (2004) claim that the corporate-owned media can and does treat certain subjects briefly and/or unsympathetically (i.e. environmental protection) while treating subjects favorable to the corporate ethic (i.e. industry, fossil fuel production) frequently and in-depth. In other words, as Widener and Gunther (2007) found, the media is able to project an image of objectivity by briefly acknowledging dissenting views without providing equal coverage to or actual explication of those opposing viewpoints. 
Moreover, even the challenging Protect \& Preserve frame focuses on only a narrow range of the environmental and social issues associated with the pipeline and therefore represents a weak version of the full environmental critique. Proponents discuss oil spills, dirty energy, and "environmental disaster" but fail to mention that it would also dramatically accelerate climate change, generate massive water waste and pollution, destroy pristine forest and indigenous lands, and threaten the health, safety, and livelihoods of vulnerable populations. ${ }^{3}$ This is partly due to the limited time environmental advocates are allocated to get their point across, but it also to the fact that the "environmental perspective" in television news broadcasts is almost exclusively provided by mainstream environmental organizations. These organizations tend to focus on the middle class concerns of their constituents (e.g. protection of wilderness, residential zoning) over the environmental justice concerns of poor communities and communities of color (Faber 2008).

\section{Methodological and Theoretical Considerations}

This research analyzes leading network and cable news sources, but it does not examine every television news station that covered the Keystone XL pipeline. This research, therefore, only speaks to how the Keystone XL pipeline was presented in the outlets under consideration. Furthermore, this research does not claim to describe every frame in television news coverage of Keystone XL. Rather, it focuses on the most prominent frames that occurred across the three network and three cable stations

\footnotetext{
${ }^{3}$ Charpentier (2009); Levi (2009); Nikiforuk (2008); National Wildlife Federation (2010)
} 
analyzed. It is therefore not an exhaustive account of media representations of the Keystone XL pipeline, but a picture of the dominant frames used to discuss it. Finally, due to the nature of the study and the time and resource constraints associated with it, every effort was made to adhere to the coding scheme, but without a second coder there was not an opportunity to maintain inter-coder reliability.

\section{Future Research}

This study focused on representations of the Keystone XL pipeline in mainstream television news outlets; however, it would also be useful to examine how the pipeline was presented in other news formats. Studies have shown that individuals who get their information from newspapers as compared to television tend to have higher levels of political knowledge and are better informed about specific issues (Bennett 1989). As such, future comparative research of this nature would be beneficial. Comparisons with independent media outlets would also add to our understanding of the effects of corporate ownership on media representations of environmental issues. Finally, expanding the analysis of the Keystone XL pipeline debate to investigate the social impacts of similar projects would be highly instructive. Subsequent studies might seek to understand how vulnerable communities (e.g. First Nations communities in Canada, communities of color near Gulf Coast refineries) are affected by transnational oil pipelines in order to refine our sociological understanding of how society negotiates its relationship to the environment and distributes associated risks and rewards. 


\section{Conclusion}

This research sought to examine what kind of information was provided by the mainstream television news media about the Keystone XL pipeline proposal, the context in which this information was presented, the sources that shaped the discourse about the pipeline, and the frames that were employed to discuss the project. In summary, television news networks failed to provide critical information in a timely manner, overwhelmingly presented favorable claims about the pipeline, and neglected to vet those claims for accuracy, which translates into biased coverage that encouraged viewers to support pipeline construction. Furthermore, news stations' marginalization of environmental and social concerns and overreliance on business and government sources afforded viewers a very limited basis for understanding the environmental and ultimately social threats posed by Keystone XL. Finally, the dominant frame employed by the news media to discuss the pipeline proposal was informed by neoliberal ideology and offered no challenge to the political and economic status quo or the preferences of corporate and government elites. Given this type of coverage, it is not unexpected that the Keystone XL pipeline would be overwhelmingly supported by the American public. Taking the political economy of the mass media into account, this research suggests that even in light of what we know about global climate change in the $21^{\text {st }}$ century, we should not expect the mainstream media to entertain any serious or sustained challenge to the Keystone XL pipeline, tar sands development, or the continuation of carbon-based economies as long as these activities are supported and championed by elites who have an interest in the continued dominance of the fossil fuel industry. 


\section{REFERENCES}

Anderson, Allison. 2009. "Media, Politics and Climate Change: Towards a New Research Agenda." Sociology Compass, 3(2): 166-182.

Babbie, Earl R. 2002. The basics of social research. Belmont, CA: Wadsworth Thomson Learning.

Bagdikian, B. H. 2004. The New Media Monopoly. Boston: Beacon Press.

Bagdikian, B.H. 2007. Pp. 66-76 in Do the media govern? Politicians, voters, and

reporters in America, edited by Iyengar, S., \& Reeves, R. Thousand Oaks, Calif: Sage Publications.

BBC World Service. 2007. "Man Causing Climate Change - Poll." Retrieved May 10, 2012. (http://news.bbc.co.uk/2/hi/in depth/7010522.stm\#map).

Bennett, Stephen Earl. 1989. "Trends in Americans' Political Information, 1967-1987". American Politics Research 17(4): 422-435.

Block, Fred. 1987. Revising state theory: essays in politics and postindustrialism. Philadelphia: Temple University Press.

Boykoff, Maxwell T. 2007. "Lost in translation? United States television news coverage of anthropogenic climate change, 1995-2004." Climatic Change 86(1-2):1-11.

Boykoff, Maxwell T. and Jules M. Boykoff. 2007. "Climate change and journalistic norms: A case-study of US mass-media coverage.” Geoforum 38(6):1190-1204.

Boykoff, Maxwell T. 2009. "We Speak for the Trees: Media Reporting on the Environment. Annual Review of Environment and Resources 34(1):431-457.

Brulle, Robert. 2009. "U.S. Environmental Movements." Pp. 211-227 in Twenty lessons in environmental sociology, edited by Gould, Kenneth Alan, and Tammy L. Lewis. New York, NY: Oxford University Press.

Cable News Network. 2011. "Keystone Pipeline: How Many Jobs it Would Really Create." Retrieved March 21, 2012. (http://money.cnn.com/2011/12/13/news/ economy/keystone_pipeline_jobs/index.htm).

Carvalho, Anabela. 2005. "Representing the politics of the greenhouse effect". Critical Discourse Studies 2(1): 1-29.

Carvalho, Anabela. 2007. "Ideological Cultures and Media Discourses on Scientific Knowledge: Re-reading News on Climate Change." Public Understanding of Science 16: 23-43. 
Charpentier, Alex, Joule A Bergerson, and Heather L MacLean. 2009. "Understanding the Canadian oil sands industry's greenhouse gas emissions." Environmental Research Letters 4(1).

Cohen, B. 1963. The Press and Foreign Policy. Princeton, NJ: Princeton University Press.

Cornell University Global Labor Institute. 2011. "Pipe Dreams? Jobs Gained, Jobs Lost by the Construction of Keystone XL.” Retrieved March 21, 2013. (http://www.ilr.cornell.edu/globallaborinstitute/research/upload/GLI KeystoneXL012312_FIN-2.pdf).

Crenson, Matthew A. 1971. The Un-Politics of Air Pollution: A Study of Nan-Decision Making in the Cities. Baltimore, MD: Johns Hopkins University Press.

Daley, P., \& O'Neill, D. 1991. "Sad Is Too Mild a Word": Press Coverage of the Exxon Valdez Oil Spill. Journal of Communication 41(4): 42-57.

Dispensa, Jaclyn Marisa, and Robert J Brulle. 2003. "Media's social construction of environmental issues: focus on global warming - a comparative study". International Journal of Sociology and Social Policy 23(10): 74-105.

Domhoff, G. William. 2005. Who Rules America? Power, Politics, and Social Change. New York: McGraw-Hill.

Entman, Robert M. 1993. "Framing: Toward Clarification of a Fractured Paradigm." Journal of Communication 43:51-58

Faber, Daniel. 2008. Capitalizing on environmental injustice: the polluter-industrial complex in the age of globalization. Lanham: Rowman \& Littlefield Publishers.

Feldman L., Maibach E.W., Roser-Renouf C., and Leiserowitz A. 2012. "Climate on cable: The nature and impact of global warming coverage on Fox news, CNN, and MSNBC". International Journal of Press/Politics. 17(1): 3-31.

Foster, John Bellamy. 2002. Ecology Against Capitalism. New York: Monthly Review Press.

Freudenburg, William R. and Frederick H. Buttel. 1999. "Expert and Popular Opinion Regarding Climate Change in the United States." Pp. 49-57 in Climate Change Policy in Germany and the United States, edited by R. Coppock, E. McGarraugh, S. Rushton, and R. D. Tuch. Washington, DC: German-American Academic Council Foundation. 
Freudenberg, William R. and Violetta Muselli. 2010. "Global Warming Estimates, Media Expectations and the Asymmentry of Scientific Challenge." Global Environmental Change 20:483-91.

Friends of the Earth. 2012. The Keystone XL Pipeline. Retrieved May 2, 2012. (http://www.foe.org/projects/climate-and-energy/tar-sands/keystone-xl-pipeline).

Gallup, Inc. 2012. “Americans Favor Keystone XL Pipeline.” Retrieved May 4, 2012. (http://www.gallup.com/poll/153383/americans-favor-keystone-pipeline.aspx).

Gamson, William A. and Kathryn E. Lasch. 1983. "The Political Culture of Social Welfare Policy" in Evaluating the welfare state: Social and political perspectives, edited by Spiro, S. E., Yuchtman-Yaar, E., \& M. P. Sapir. . New York: Academic Press.

Gamson, William A. and Andre Modigliani. 1989. "Media Discourse and Public Opinion on Nuclear Power: A Constructionist Approach." American Journal of Sociology 95:1-37.

Gamson, William A, David Croteau, William Hoynes, and Theodore Sasson. 1992. "Media Images and the Social Construction of Reality." Annual Review of Sociology 18(1).

Gentzkow, Matthew, and Jesse M. Shapiro. 2010. "What Drives Media Slant? Evidence From U.S. Daily Newspapers". Econometrica. 78(1): 35-71.

Gitlin, Todd. 1980. The whole world is watching: mass media in the making \& unmaking of the New Left. Berkeley: University of California Press.

Goffman, Erving. 1974. Frame Analysis: An Essay on the Organization of Experience. Cambridge, MA: Harvard University Press.

Gramsci, Antonio. 1971. Selections from the Prison Notebooks. New York: International Publishers.

Hall, Stuart. 1995. "The Rediscovery of 'Ideology': Return of the Repressed in Media Studies." Pp. 56-90 in Approaches to media: a reader, edited by Boyd-Barrett, Oliver, and Chris Newbold,. London: E. Arnold.

Hall, S., Critcher, C., Jefferson, T., Clarke, J., \& Roberts, B. 1978. “The social production of news." Pp. 53-77 in Policing the crisis: Mugging, the state, and law and order, edited by S. Hall. New York: Holmes \& Meier.

Hansen, James. 2012. “Game Over for the Climate.” The New York Times, May 9, 2012. Retrieved June 10, 2012. (http://www.nytimes.com/2012/05/10/opinion/gameover-for-the-climate.html). 
Hart, Philip. 2011. "One or Many? The Influence of Episodic and Thematic Climate Change Frames on Policy Preferences and Individual Behavior Change". Science Communication. 33(1): 28-51.

Herman, E. S., \& Chomsky, N. 1988. Manufacturing consent: The political economy of the mass media. New York: Pantheon Books.

Iyengar, Shanto. 1991. Is Anyone Responsible? How Television Frames Politics Issues. Chicago,IL: The University of Chicago Press.

Jenkins, J. C. 2011. "Democratic Politics and The Long March On Global Warming: Comments on Mccright and Dunlap.” Sociological Quarterly (52)2: 211-219.

Levi, Michael A. 2009. The Canadian oil sands: energy security vs. climate change. New York: Council on Foreign Relations, Center for Geoeconomic Studies.

Lukes, Steven. 1974. Power: A Radical View. London: Macmillan Press.

Mander, Jerry. 1978. Four arguments for the elimination of television. New York: Morrow.

Mazur, Allan. 2006. "Risk Perception and News Coverage across Nations. Risk Management 8(3):149-174.

McChesney, Robert. 1999. "Noam Chomsky and the Struggle Against Neoliberalism." Monthly Review New York 50(11):40-47.

McChesney, Robert. 2003. "The Problem of Journalism: a political economic contribution to an explanation of the crisis in contemporary US journalism." Journalism Studies 4(3):299-329.

McCright, Aaron and Riley Dunlap. 2000. "Challenging Global Warming as a Social Problem: An Analysis of the Conservative Movement's Counter-Claims". Social Problems. 47 (4).

McCright, Aaron and Riley Dunlap. 2003. "Defeating Kyoto: The Conservative Movement's Impact on U.S. Climate Change Policy.” Social Problems 50(3): 348-373.

Mills, C. Wright. 1956. The power elite. New York: Oxford University Press.

Molotch, Harvey, and Marilyn Lester. 1975. "Accidental News: The Great Oil Spill as Local Occurrence and National Event". American Journal of Sociology. 81(2).

Molotch, Harvey. 1970. "Oil in Santa Barbara and Power in America." Sociological Inquiry 40(13):1-44. 
Morris, J. S. 2005. "The Fox News Factor." The Harvard International Journal of Press/Politics 10(3):56-79.

National Science Foundation. 2010. "Science and Technology: Public Attitudes and Understanding.” Retrieved May 2, 2012. (http://www.nsf.gov/statistics/ seind10/c7/c7s1.htm).

National Wildlife Federation. 2010. Assault on America a decade of petroleum company disaster, pollution, and profit. Reston, VA: National Wildlife Federation.

The New York Times. 2013. "Pipeline Spills Stir New Criticism of Keystone Plan." Retrieved April 15, 2013. (http://www.nytimes.com/2013/ 04/03/ us/pipeline-spills-stir-new-criticism-of-keystone-proposal.html).

The New York Times. 2012. "Keystone XL Pipeline Decision to be Investigated." Retrieved January 18, 2012. (http://www.nytimes.com/2011/11/08/science/earth/ inquiry-into-keystone-xl-pipeline-permit-process.html).

Nikiforuk, Andrew. 2008. Tar sands: dirty oil and the future of a continent. Vancouver: Greystone Books.

Nisbet, Matthew C. and Theresa Myers. 2007. "Twenty Years of Public Opinion about Global Warming.” Public Opinion Quarterly 71(3): 444-470

Nisbet, Matthew C. 2009. "Communicating Climate Change: Why Frames Matter for Public Engagement". Environment. 51(2).

Page, Benjamin I., Robert Y. Shapiro, and Glenn R. Dempsey. 1987. "What Moves Public Opinion?" The American Political Science Review. 81(1): 23-43.

Page, Benjamin I., and Robert Y. Shapiro. 1992. The Rational Public: Fifty Years of Trends in Americans' Policy Preferences. Chicago: University of Chicago Press.

Parekh, Bhikhu C. 1982. Marx's theory of ideology. Baltimore: Johns Hopkins University Press.

Parenti, M. 1986. Inventing reality: The politics of the mass media. New York: St. Martin's Press.

The Pew Center on Global Climate Change. 2012. The Basics of Climate Change. Retrieved February 18, 2012. (http://www.pewclimate.org/global-warmingbasics/about). 
The Pew Research Center. 2009. "Fewer Americans See Evidence of Global Warming." Released October 22. Retrieved November 19, 2011 (http://www.peoplepress.org/2009/10/22/fewer-americans-see-solid-evidence-of-global-warming).

The Pew Research Center. 2010. Americans Spending More Time Following the News. Released September 12. Retrieved November 19, 2011. (http://www.peoplepress.org/2010/09/12/americans-spending-more-time-following-the-news).

Rees, William and Laura Westra. 2003. "When consumption does violence : can there be sustainability and environmental justice in a resource-limited world?" Pp. 99-124 in Just Sustainabilities: Development in an Unequal World., edited by Agyeman, J., R.D. Bullard, and B. Evans. Cambridge, Mass: MIT Press.

Rudel, Thomas K., J. Timmons Roberts, and JoAnn Carmin. 2011. "Political Economy of the Environment". Annual Review of Sociology. 37: 221-238.

Ryan, Charlotte. 1991. Prime time activism $\square$ : media strategies for grassroots organizing. Boston, MA: South End Press.

Schnaiberg, Allan. 1994. "The Political Economy of Environmental Problems and Policies: Consciousness, Conflict, and Control Capacity." Advances in Human Ecology 3:23-64.

Schneider, Stephen H. 1993. "Degrees of Certainty." Research and Exploration 9(2):173190.

Schwartz, Michael, Laura Anker and Peter Seybold. 1987. "The Ties That Bind Business and Government" in The Structure of Power in America: The Corporate Elite as a Ruling Class, edited by M. Schwartz.New York: Holmes \& Meier.

Smith, C. 1993. "News Sources and Power Elites in News Coverage of the Exxon Valdez Oil Spill". Journalism Quarterly 70 (2): 393.

United Nations Framework Convention on Climate Change. 2012. "Changes in Greenhouse Gas Emissions of Individual Annex I Parties, 1990-2009." Retrieved May 4, 2012. (http://unfccc.int/ghg_data/ghg_data_unfccc/ items/4146.php).

United States Department of State. 2011. "Final Environmental Impact Statement for the Proposed Keystone XL Project.” Retrieved May 4, 2012. (http://keystonepipelinexl.state.gov/documents/organization/182010.pdf)

Van Gorp, Baldwin. 2007. "The Constructionist Approach to Framing: Bringing Culture Back In". Journal of Communication. 57 (1). 
Widener, Patricia, and Valerie J. Gunter. 2007. "Oil Spill Recovery in the Media: Missing an Alaska Native Perspective". Society \& Natural Resources. 20(9).

Winett, Liana. 1997. "Do the Media Govern?" Pp. 420-433in Do The Media Govern? edited by Shanto Iyengar and Richard Reeves. Thousand Oaks: Sage Publications. 


\section{APPENDIX A: FRAME MATRIX}

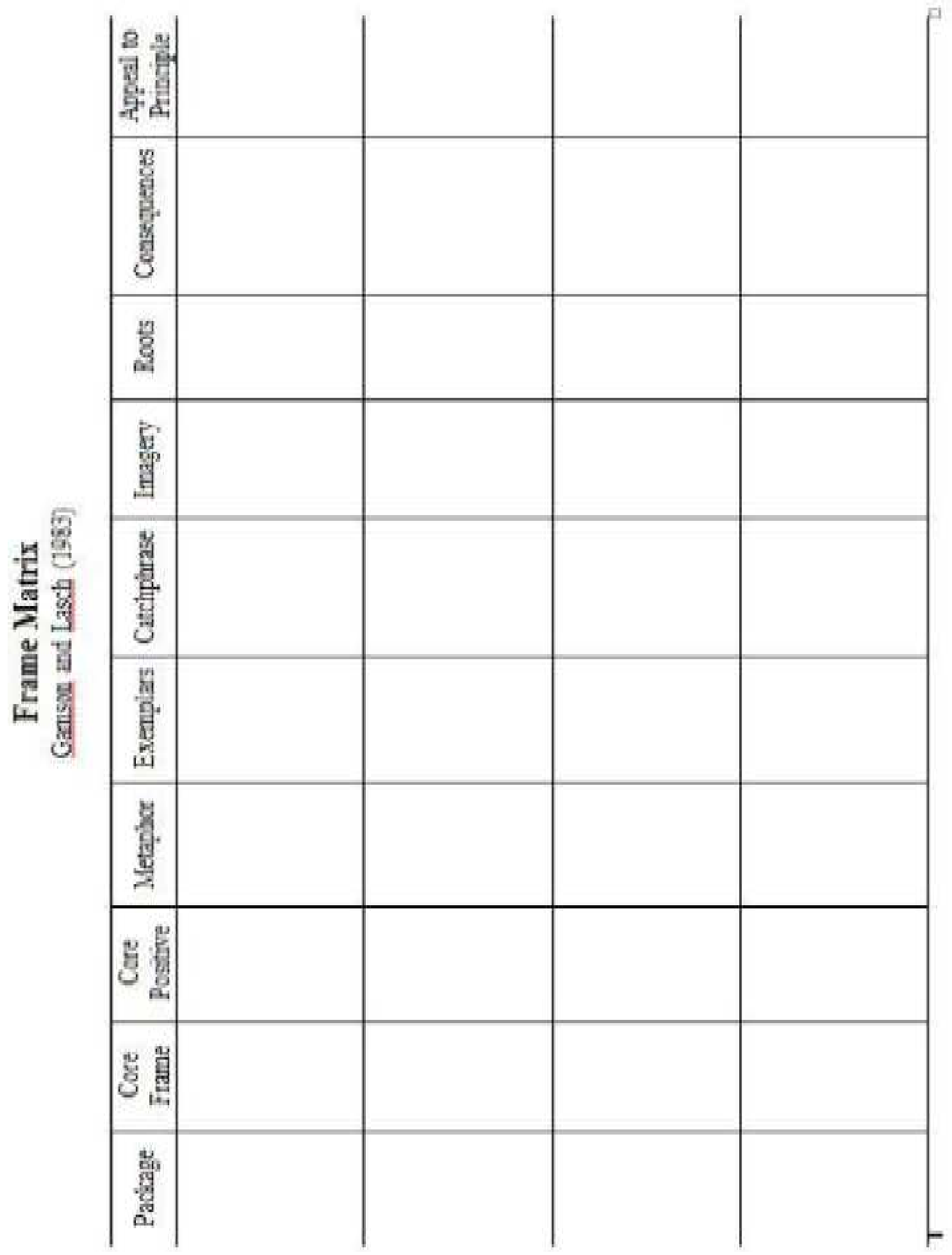




\section{APPENDIX B: Code Sheet}

Transcript \#

Date:

Station

Tally of Claims: Pro

"Jobs"___ "Gas Prices"___ "Energy Independence" __ "National Security"

Tally of Claims: Con

__ "Environmental Risks/Concerns"___ "Contributes to Climate Change"__ "Dirty"

Tally of Issues Mentioned:

Jobs

Gas Prices

National Interest

Politics

More Time Needed

Consider the Environment

Protest

Alternatives to Fossil Fuels

Climate Change

\section{Sources Consulted:}

Government

Business

Environment

Labor

Scientist
Name/affiliation

Name/affiliation

Name/affiliation

Name/affiliation

Name/affiliation

\section{Other Notes:}

